\title{
The real exchange rate and economic development ${ }^{\text {th }}$
}

\author{
Arslan Razmi*, Martin Rapetti, Peter Skott \\ Department of Economics, University of Massachusetts, Amherst, MA 01003, United States
}

\section{A R T I C L E I N F O}

\section{Article history:}

Received July 2011

Accepted January 2012

Available online xxx

\section{JEL classification:}

F43

011

041

\section{Keywords:}

Real exchange rates

Underemployment

Capital accumulation

Investment

Growth

\begin{abstract}
A B S T R A C T
Recent empirical studies have found a robust correlation between competitive exchange rates and economic growth in developing economies. This paper presents (i) a formal model to help explain these findings and (ii) econometric evidence on the relation between investment and the real exchange rate. The model emphasizes the existence of (hidden) unemployment as a source of endogenous growth, even under constant returns to scale. Growth promoting policies, however, affect the external balance, and two instruments are needed in order to achieve targets for both the growth rate and the trade balance. The real exchange rate can serve as one of those instruments. The implications of the model for the relation between real exchange rates and the rate of capital accumulation find support in our econometric analysis.
\end{abstract}

(c) 2012 Elsevier B.V. All rights reserved.

\section{Introduction}

Recent studies have found a robust correlation between competitive exchange rates and economic growth. An interesting example is the study by Hausmann et al. (2005) which identified and analyzed determinants of 'growth episodes' in the latter half of the twentieth century and found that real exchange depreciations tend to precede sustained growth spurts. Other work includes Razin and Collins (1997), Polterovich and Popov (2002), Levy-Yeyati and Sturzenegger (2007), Gala (2008), Rodrik (2008), and

\footnotetext{
E. Early versions of this paper have been presented in seminars at the University of Antwerp, New School for Social Research, Moscow Higher School of Economics, Aarhus University, Universidad Nacional de Córdoba, International Conference on Developments in Economic Theory and Policy, and the Eastern Economic Association Meetings. We thank the participants and Jaime Ros for helpful comments and suggestions.

* Corresponding author. Tel.: +1 413 5770785; fax: +1 4135452921.

E-mail addresses: arazmi@econs.umass.edu (A. Razmi)

mrapetti@econs.umass.edu (M. Rapetti), pskott@econs.umass.edu (P. Skott).
}

Berg et al. (2008). This emerging body of empirical evidence - along with East Asia's rapid accumulation of reserves in the pursuit of what is widely seen as 'export-led growth' has stimulated interest in the theoretical linkages between the real exchange rate and growth.

The growth enhancing effects of competitive exchange rates are found primarily in developing countries, ${ }^{1}$ and this finding motivates our approach in this paper. Unlike developed economies, LDCs typically have large amounts of (hidden) unemployment and the development process involves the mobilization of these unemployed resources. An obvious example is China where record growth rates over the last three decades have involved moving millions of workers from the rural hinterland to the industrialized urban areas, mainly in the coastal provinces in the south and south east. The rural areas have low productivity and significant under- and informal employment, and the goods produced in these informal sectors tend to be relatively non-traded in nature.

\footnotetext{
1 See, for example, Rapetti et al. (2011).
} 
The classic Lewis model captures the dual character of developing economies and the elastic supply of labor to the modern sector but pays little attention to trade and aggregate demand. These aspects are addressed in openeconomy versions of Keynesian and Kaleckian models in which depreciations tend to boost demand and raise output in the short-run. A redistribution of income towards profits, moreover, can stimulate long-run growth in a profit-led regime in these models. ${ }^{2}$ The 'balance of payments constrained' growth model (BPCG), first developed by Thirlwall (1979), adds to this argument by suggesting that the need for external balance puts a limit on the sustainable levels of aggregate demand. ${ }^{3}$ To the extent that real exchange rate depreciations relax the external constraint, a depreciation would promote growth in this framework.

Like the Kaleckian and BPGC models, the model in this paper focuses on the mobilization of unemployed resources, but there are important differences. Both the Kaleckian and the BPCG models emphasize quantity adjustments over external relative price adjustments, and the real exchange rate is often treated as an exogenously given constant in these models. Real depreciations, moreover, may be expansionary, but the specifications of export and import functions in most BPGC models imply that continuously depreciating exchange rates are required in order to obtain a lasting effect on growth. Our analysis, by contrast, sees the real exchange rate as a key variable, and we assume that the demand for exports is perfectly elastic.

We set up a stylized model of a small open economy with two sectors; a modern sector produces a tradable good while the output of the traditional sector is non-tradable. Only the former uses capital and, owing to the underdeveloped nature of the industrial sector, all capital goods are imported. The framework has affinities with the 'dependent economy model,' but unlike the standard versions of this model, we assume that there is substantial hidden or open unemployment.

The model implies that changes in the real exchange rate affect the level and composition of employment and that the real exchange rate can, therefore, be used to facilitate sustained capital accumulation and economic growth. The basic intuition behind these results is straightforward. Growth is endogenous in a dual economy without full employment, as evidenced for instance by the classic Harrod-Domar and Lewis models. This endogeneity of the growth rate also applies to open economies, but in open economies one needs to consider the implications of growth promoting policies for the external balance. An increase in the growth rate may require a more competitive exchange rate, and this adjustment need not happen automatically. ${ }^{4}$ Recently, Rodrik (2009)[p. 23] has argued

\footnotetext{
2 See, for example, Blecker (2002). To the extent that they come at the expense of other countries, these effects in Kaleckian models have a beggar-thy-neighbor flavor. See Blecker and Razmi (2008) for an investigation of the "fallacy of composition" argument.

3 See Porcile and Lima (2010) for a recent contribution in this tradition.

4 See, for example, Chinn and Wei (2008). The lack of exchange rate adjustment in the face of external imbalances may hinder growth, as has been eloquently illustrated in recent decades by the economic performance of several developing countries that experienced stop-and-go
}

that, in the presence of trade balance constraints, "industrial policy can be assigned to the structural transformation target while the exchange rate is assigned to the external balance." Our model can be interpreted as a formal development of this argument.

Mainstream macroeconomic theory has traditionally seen the real exchange rate as an endogenous variable whose value is determined in a general equilibrium set-up by 'deeper' parameters such as preferences, factor endowments, and productivity. In accordance with this view, the role of exchange rate policy in causing or sustaining growth has been played down. A body of literature shows, however, that the real exchange rate tracks the nominal exchange rate quite closely over time which suggests that targeting the latter may effectively target the former as well, at least in the short- and medium-run. Moreover, the ability of policy to target the exchange rate in the presence of capital mobility may have been underestimated. Governments have a variety of policy options including monetary and fiscal policy, saving incentives, capital controls, and reserve management, and the evidence suggests that governments do indeed use these instruments to influence exchange rates. ${ }^{5}$ These empirical observations are consistent with the model in this paper. The model has a continuum of equilibrium paths. All of the paths have balanced trade, but the growth rates and the real exchange rates differ across paths, and the existence of these different paths leaves an opening for policy to influence the outcome.

The empirical part of the paper examines the implications of the model for the relationship between real exchange rate changes and the rate of capital accumulation. In the absence of a sophisticated industrial sector that has the capacity to supply domestic capital goods requirements, a more ambitious accumulation target requires an undervalued exchange rate to offset the effects on the external balance. We show that real exchange rate undervaluations are (statistically) significant drivers of investment growth, but only in developing countries. This result, which is in line with the model, is robust to different specifications, controls, and econometric methods.

To the extent that underemployment of resources and the balance of payments constraint play a crucial role, two important recent papers that perhaps come closest to this contribution are Gala (2008) and Porcile and Lima (2010). However, the former explicitly focuses on the short run, assuming adjusting capacity utilization and nominal wage rigidity and, unlike our two-sector version of a small open economy, both use a one-good model with mark-up pricing in an "imperfect substitutes" framework. The Porcile and Lima study is purely theoretical while

cycles during which foreign exchange shortages typically led to the interruption of growth instead of smooth exchange rate depreciations.

5 A detailed discussion of these policy issues is beyond the scope of this paper but see, for example, the 'fear of floating' literature emanating from Calvo and Reinhart (2002), who show that, in the aftermath of the Asian crises, developing countries have systematically intervened in the foreign exchange market to manage the behavior of exchange rates. Levy-Yeyati and Sturzenegger (2007) find evidence that in the 2000s such interventions have aimed to maintain competitive exchange rates or to avoid overvaluations. 
Gala has an empirical section. Unlike our focus on the investment-real exchange rate relationship, however, he explores the growth-real exchange rate nexus. Moreover, in order to evaluate whether the real exchange rate affects investment mainly through the negative effects of overvaluation (the "Dutch disease" effect), we dig deeper by investigating possible asymmetries between under- and overvaluation, between small and large misalignments, and between developing and high-income economies. ${ }^{6}$

The paper falls in six sections. The benchmark model is presented in Section 2. We analyze the long-run implications of the model in Section 3 and consider the short run in Section 4. Section 5 discusses the econometrics and presents the results. Section 6 concludes.

\section{A long-run model}

The benchmark model is kept simple. It captures, we believe, important features of most low income countries, and many of the assumptions can be relaxed without affecting the qualitative conclusions (see Appendix A). ${ }^{7}$

We consider a small open economy with a non-tradable and a tradable goods sector. Investment goods are imported while the domestically produced tradable good can be used for domestic consumption or export. The non-tradable good is produced using labor (and a fixed supply of land),

$Y_{N}=A L_{N}^{\beta} ; \quad 0<\beta \leq 1$

where $Y_{N}, L_{N}$ denote output and employment in the nontradable sector. Under profit maximization and perfect competition, the income share of labor would be constant and equal to $\beta$. We shall retain the assumption of constant distributive shares in the non-tradable sector but take the share of wages to equal $v \beta$. Deviations from marginal productivity pricing could occur for a number of reasons, including monopsonistic effects or imperfect competition in the product market (which would imply $v<1$ ) and the influence of social norms and conventions (with $v \gtrless 1$ ). We do not make any specific assumption about the value of $v$ but restrict the product $\nu \beta$ (the share of labor) to be strictly less than one. 8

Empirical measures of the real wage in a traditional, non-tradable sector may be hard to interpret in the presence of hidden unemployment and underemployment.

\footnotetext{
6 Bahmani-Oskoee and Hajilee (2010) do address the devaluationinvestment nexus. However, in addition to the other caveats just discussed, this paper is purely empirical and focuses on individual countries rather than panel data. Moreover, the construction of the key variable, i.e., the real exchange rate, does not take into account the BalassaSamuelson effect. See also Campa and Goldberg (1999), which studies four industrialized countries.

7 The model eschews explicit intertemporal optimization by a representative agent, following instead an eclectic, Keynesian approach. One advantage of the eclectic approach is that by assuming exogenous saving rates (instead of full intertemporal optimization by a single representative agent) the interaction between different sectors and agents can be analyzed in a fairly simple and transparent way.

8 The condition $\nu \beta<1$ is needed to ensure the existence of an equilibrium solution when workers in the traditional sector spend their entire income on non-traded goods. Once we relax this latter assumption (see Appendix A), this condition is no longer needed.
}

Our distributional assumptions imply that the wage share is uniquely determined, but the effective labor input $L_{N}$ may be spread across a larger number of workers and/or involve a larger amount of low intensity work. We therefore consider two distinct measures of the real wage in the traditional sector. One of them, the 'effective wage' $\omega_{N}$, is found by dividing the well-defined total wage payment by the effective labor input $L_{N}$ :

$\omega_{N}=\frac{w_{N}}{p_{N}}=v \beta A L_{N}^{\beta-1} ; \quad 0<v \leq 1, v \beta<1$

An alternative measure assumes that the traditional sector is characterized by work sharing. If unemployment takes the form of underemployment, the empirically measured wage in the traditional sector may be the average remuneration, that is, total labor income divided by the number of workers not employed in the formal sector. This 'sharing wage' $\left(\tilde{\omega}_{N}\right)$ is given by

$\tilde{\omega}_{N}=\frac{\omega_{N} L_{N}}{L-L_{T}} \leq \omega_{N}$

where $L_{T}$ is employment in the tradable sector. Depending on institutional characteristics, the measured wage in the traditional, non-tradable sector may fall anywhere between the sharing wage $\tilde{\omega}_{N}$ and the effective wage $\omega_{N}$.

Tradable goods are produced in the formal (advanced, capitalist) sector. This sector uses both labor and capital, and for simplicity a fixed coefficient production function is assumed, i.e.,

$Y_{T}=\min \left\{a L_{T}, \bar{b} K\right\}$

where $Y_{T}, L_{T}$ and $K$ denote output, employment, and capital in the tradable goods sector. The parameters $a$ and $\bar{b}$ are taken to be fixed, and we assume that there is no labor hoarding and that capital utilization is at the desired rate $\bar{u}$. Hence,

$Y_{T}=a L_{T}=\bar{u} \bar{b} K=b K$

where $\bar{u}$ is desired utilization and $b=\bar{u} \bar{b}$. The utilization assumption will be modified in Section 4 when we address short-run issues.

Labor is mobile across sectors. However, workers in the tradable sector may receive a wage premium, and we take the tradable-sector real wage to be determined by the tradable-sector employment rate $L_{T} / L$, the relative price of tradables $q$, and the saving rate $s$,

$\omega_{T}=\frac{w_{T}}{p_{N}}=\phi\left(\frac{L_{T}}{L}, q, s\right) ; \quad \phi_{1} \geq 0, \phi_{2} \geq 0, \phi_{3} \leq 0$

A wage premium may exist in the modern tradable sector for a variety of reasons, including principal-agent problems (efficiency wages) and bargaining in the presence of costly search and relationship-specific investment. The value of the sharing wage $\tilde{\omega}_{N}$ along with the tradable-sector employment rate $L_{T} / L$ are key determinants of workers' fallback position in both efficiency wage and bargaining models, and the general specification in Eq. (6) is consistent with tradable-sector wages being determined as a markup on the sharing wage, with the markup as a function of employment and the exchange rate: $\omega_{T}=\lambda\left(\frac{L_{T}}{L}, q\right) \tilde{\omega}_{N}$ (see note 12 below). The real exchange rate enters the 
$\phi$-function both because it determines the total revenue (the size of the 'pie') in the tradable sector and may affect the size of the wage premium $\lambda$ and because of its influence on the demand for non-tradables, non-tradable employment and the sharing wage; the saving rate enters the $\phi$-function because it affects the demand for nontradables and the sharing wage.

By definition, the equilibrium condition for nontradables is given by

$Y_{N}=E_{N}$

where $E_{N}$ is the domestic demand for the non-tradables. We assume that the non-tradables are used only for consumption. Workers do not save and consume only nontradables. Non-workers (capitalists and landlords), on the other hand, save a fraction $s$ of their income and consume both non-tradables and tradables. Thus, the demand for non-tradables can be written

$E_{N}=\omega_{N} L_{N}+\omega_{T} L_{T}+\alpha(1-s)\left[q b K-\omega_{T} L_{T}+(1-v \beta) A L_{N}^{\beta}\right]$

where $\alpha$ is the proportion of capitalist and landlord consumption that is spent on the non-tradable. These assumptions about saving rates and the demand for nontradables are made because they fit the stylized facts for LDCs; Appendix A examines the implications of allowing worker saving and worker consumption of tradables. ${ }^{9}$

The proportion $\alpha$ depends on $q$, and if tradable and non-tradables are gross substitutes (the likely case), the dependence is positive

$\alpha=\alpha(q), \quad \alpha^{\prime}>0$

The tradable good can be exported or consumed domestically. We take world demand to be perfectly elastic at a given price in foreign currency, $p_{T}$, and with a given supply of tradables, the equilibrium condition for the tradable goods sector serves to determine the trade balance net of investment (or, equivalently, the net exports of the tradable good),

$X_{T}=Y_{T}-E_{T}$

Clearly, it can be difficult to break into new export markets, and the infinite-elasticity assumption will be modified in the short run analysis (see Section 4).

\footnotetext{
9 The saving propensity out of wages is small in most developing economies. Even for high saving countries like China, the bulk of the saving comes from profit and rent income. One indirect piece of evidence in this regard comes from the oft-cited empirical regularity that the wage share of national income in developing countries tends to be positively correlated with the consumption share. World Bank (2007, p. 6) illustrates the co-movement of these variables in China in recent years, and Kuijs (2006) finds that while Chinese household saving out of disposable income (which includes some interest, rent and profit income) is high what makes the saving to GDP ratio exceptional is the presence of high enterprise and government savings.

Data for a number of developing countries from LABORSTA (2009) suggest that the proportion of household expenditures devoted to food and housing decreases, while that devoted to clothing and "other manufactures" increases as we move up the income distribution.
}

The domestic consumption demand for the tradable good is given by

$E_{T}=(1-\alpha)(1-s)\left[q b K-\omega_{T} L_{T}+(1-v \beta) A L_{N}^{\beta}\right] / q$

and the relative price of tradables, which is our long-run measure of the real exchange rate, can be written

$q=\frac{e p_{T}}{p_{N}}$

where $e$ is the nominal exchange rate (i.e., the domestic currency price of foreign currency). All capital goods are imported at a world market price $p_{K}$ in foreign currency. Thus, the trade balance (in terms of non-tradables) can be written

$T B=q\left(X_{T}-\frac{p_{K}}{p_{T}} I\right)=q\left(Y_{T}-E_{T}-\frac{p_{K}}{p_{T}} I\right)$

Trade need not be balanced in the short run but sustainability requirements constrain the value of the trade balance (relative to the size of the economy) in the long run. For simplicity, we assume that in the long run

$T B=0$

The accumulation rate in the tradable goods sector depends on its profitability and the cost of investment. ${ }^{10}$ Formally,

$$
\begin{gathered}
\frac{I}{K}=f(r, \gamma)=f\left(b \frac{p_{T}}{p_{K}}\left(1-\frac{\phi\left(\frac{L_{T}}{L}, q, s\right)}{a q}\right), \gamma\right) ; \\
f_{r}>0, f_{\gamma}>0
\end{gathered}
$$

where $\gamma$ can be interpreted as a policy variable that affects the incentive to invest. We take this policy variable to be an inverse measure of the cost of finance/the interest rate, rather than, say, a government subsidy to investment which would need to be financed, adding variables to the model. The direct effect of a depreciation on accumulation is ambiguous. This ambiguity may seem surprising, but the intuition is simple: a depreciation raises the demand for non-tradables and thereby stimulates both employment and the "sharing wage" $\tilde{\omega}_{N}$. The result is upward pressure on real wages in the tradable sector, and depending on the strength of this effect, tradable sector profitability can go either way. Thus, depending on the precise functional form of the wage Eq. (6), a real depreciation may raise or lower the rate of accumulation. ${ }^{11}$

Finally, real aggregate income and aggregate domestic demand, both in terms of non-tradables, are given by

$Y=Y_{N}+q Y_{T}$

$E=E_{N}+q E_{T}+q \frac{p_{K}}{p_{T}} I$

\footnotetext{
10 Domestic investment could also depend on the foreign profit rate but - in line with the small open economy assumption - this is taken to be exogenous and constant.

11 More specifically, a rise in $q$ raises the profit and accumulation rates as long as $\phi_{2} q / \phi<1$, i.e., the elasticity of the real wage in the tradable sector with respect to the real exchange rate is less than unity. This condition is likely to be satisfied in an economy with significant underemployment.
} 


\section{The real exchange rate and economic growth}

\subsection{Analysis}

Tradable-sector employment is determined by the capital stock,

$L_{T}=\frac{b}{a} K$

and, substituting (18) into (6), the tradable-sector wage can be written

$\omega_{T}=\phi\left(\frac{b}{a} \frac{K}{L}, q, s\right)$

The solutions for non-tradable output, employment and wages are more involved. Using Eqs. (2) and (5)-(8), the equilibrium value of non-tradable output is

$Y_{N}=\left[\frac{\alpha(1-s) q}{(1-\alpha(1-s))}+\frac{\phi\left(\frac{b}{a} \frac{K}{L}, q, s\right)}{a}\right] \frac{b K}{(1-v \beta)}$

and effective non-tradable employment and wages are given by ${ }^{12}$

$L_{N}=\left\{\left[\frac{\alpha(1-s) q}{(1-\alpha(1-s))}+\frac{\phi\left(\frac{b}{a} \frac{K}{L}, q, s\right)}{a}\right] \frac{b K}{A(1-v \beta)}\right\}^{1 / \beta}$

$$
\begin{aligned}
\omega_{N}= & v \beta A\left\{\left[\frac{\alpha(1-s) q}{(1-\alpha(1-s))}+\frac{\phi\left(\frac{b}{a} \frac{K}{L}, q, s\right)}{a}\right]\right. \\
& \left.\frac{b K}{A(1-v \beta)}\right\} \\
\tilde{\omega}_{N}= & \frac{1}{L-L_{T}} v \beta\left[\frac{\alpha(1-s) q}{(1-\alpha(1-s))}+\frac{\phi\left(\frac{b}{a} \frac{K}{L}, q, s\right)}{a}\right] \frac{b K}{(1-v \beta)}
\end{aligned}
$$

Both tradable and non-tradable employment are increasing in $K$ (Eqs. (18) and (21)) as are wages in the tradable sector (Eq. (19)). The non-tradable sharing wage also depends positively on $K$ (Eq. (23)) but the effective real wage in the non-tradable sector is unaffected if $\beta=1$ or declines if $\beta<1$ (Eq. (22)). Non-tradable output, employment, sharing wage, and tradable-sector wages are

\footnotetext{
12 See Appendix B for more discussion of distributional effects. In the special case where $\omega_{T}=\lambda\left(\frac{L_{T}}{L}, q\right) \tilde{\omega}_{N}$, the expression for $\tilde{w}_{N}$ can be written

$\tilde{\omega}_{N}=\frac{a \nu \beta \alpha(1-s) q}{[1-\alpha(1-s)]\left[\left(1-\frac{L_{T}}{L}\right)(1-v \beta)-\frac{L_{T}}{L} \lambda \nu \beta\right]} \frac{L_{T}}{L}$

The right hand side of this equation is increasing in the formal-sector employment rate $L_{T} / L$ and the real exchange rate $q$ and decreasing in the saving rate $s$. It follows that $\omega_{T}=\lambda\left(\frac{L_{T}}{L}, q\right) \tilde{\omega}_{N}$ is a special case of the general specification in Eq. (6), $\omega_{T}=\phi\left(\frac{L_{T}}{L}, q, s\right)$.
}

increasing in $q$ and decreasing in $s$; effective wages in the non-tradable sector are decreasing in $q$ and increasing in $s$ (if $\beta<1$ ). The positive effect of $q$ on non-tradable output and employment - which is due both to income and substitution effects - flows from the existence of unemployment. In a standard full employment model, a rise in the relative price of a good would shift resources away from the sector whose relative price has declined; with unemployment and a perfectly elastic export demand, however, the change in relative prices generates an increase in non-tradable demand, and a rise in employment makes it possible to meet this extra demand.

Turning now to the trade balance, Eqs. (5)-(6), (11), (13)-(15) and (21) imply that

$$
\begin{aligned}
& \frac{T B}{q \frac{p_{K}}{p_{T}} K}=\frac{b}{\frac{p_{K}}{p_{T}}} \frac{s}{1-\alpha(1-s)}-\frac{I}{K} \\
& =\frac{b}{\frac{p_{K}}{p_{T}}} \frac{s}{1-\alpha(1-s)}-f\left(b \frac{p_{T}}{p_{K}}\left(1-\frac{\phi\left(\frac{b}{a} \frac{K}{L}, q, s\right)}{a q}\right), \gamma\right) \\
& =F\left(q ; \gamma, \frac{K}{L}\right) ; \quad F_{q} \gtrless 0, F_{\gamma}<0, F_{K} \geq 0
\end{aligned}
$$

The partials $F_{\gamma}$ and $F_{K}$ are straightforward. By assumption an increase in $\gamma$ (a decrease in the cost of finance) stimulates investment, thus reducing the trade balance; an increase in the capital stock relative to the total labor force, on the other hand, raises the tradable sector real wage which reduces profitability and accumulation. The effects of an increase in the real exchange rate, by contrast, are ambiguous: a real depreciation shifts domestic consumption toward non-tradables, thus releasing a larger proportion of tradable sector output for exports, but, as discussed following Eq. (15), it may also raise profitability and investment (and thus imports). The evidence suggests that the first of these effects generally dominates in the long run: the Marshall-Lerner-Robinson-Bickerdike condition (MLRB condition) is usually satisfied, also for LDCs. ${ }^{13}$ Assuming that this is the case, we have $F_{q}>0$ and if $T B=0$, Eq. (25) defines the real exchange rate as a function of $\gamma$ and $K$ :

$q=\eta\left(\gamma, \frac{K}{L}\right) ; \quad \eta_{\gamma}>0, \eta_{K} \leq 0$

The negative sign of $\eta_{K}$ fits the standard Balassa-Samuelson and Bhagwati-Kravis-Lipsey results: higher levels of income (higher capital stocks) are associated with an appreciated real exchange rate.

Viewed from another angle, the above analysis shows that two instruments ( $\gamma$ and $q$ ) are needed to reach two

\footnotetext{
${ }^{13}$ See, for example, Bahmani-Oskoee and Niroomand (1998) for a test of the Marshall-Lerner condition for a large sample of countries. The standard Marshall-Lerner condition focuses on demand elasticities, assuming a perfectly elastic supply. In our case this supply elasticity assumption is far from being met: the supply of traded output is constrained by the capital stock while the world demand elasticity for traded goods is taken to be infinite. Note that the MLRB condition is less stringent than the Marshall-Lerner condition.
} 
targets $((I / K)$ and $T B)$. The structure of the model is such that, given $I / K$ and $T B=0$, Eq. (24) determines $q$,

$q=\psi\left(\frac{I}{K}\right) ; \quad \psi^{\prime}>0$

where the sign of the derivative $\psi^{\prime}$ follows from the assumption that $\alpha^{\prime}>0$. The accumulation function (15) can now be used to determine $\gamma$,

$\gamma=\xi\left(\frac{I}{K}, q, \frac{K}{L}\right) ; \quad \xi_{\frac{1}{K}}>0, \xi_{q} \gtrless 0, \xi_{K} \geq 0$

Thus, given a target rate of accumulation, the trade balance condition determines the real exchange rate and the accumulation target then determines the corresponding investment incentive. Eq. (27) captures the key result: faster accumulation requires real depreciation in order to switch domestic expenditure away from tradables and make room for increased capital good imports.

As discussed earlier, the direct effect of a depreciation on accumulation is ambiguous. If the MLRB condition is satisfied, however, a rise in $q$ improves the trade-balance and even if it raises accumulation, an additional growth stimulus from reductions in the cost of finance (that is, a rise in $\gamma$ ) is necessary to avoid an improvement in the trade balance: a rise in both $q$ and $\gamma$ is needed to bring about an increase in $I / K$ while keeping $T B=0$.

The comparative statics depend on both the MLRB condition and the assumption of substitutability in consumption $\left(\alpha^{\prime}>0\right)$. If the former is violated, increased accumulation is associated with a decline in $\gamma$ but the real exchange rate still depreciates; complementarity in consumption implies that $\alpha^{\prime}<0$, and an appreciation is required in order to reduce domestic consumption of tradables and accommodate a rise in the target accumulation rate.

\subsection{Steady growth}

The capital stock affects the levels of employment and income (cf. Eqs. (18)-(23)), and the link between the exchange rate and accumulation therefore implies that the exchange rate has a growth effect, too.

A steady growth path exists if there are constant returns to labor in the non-tradable sector $(\beta=1)$ and the labor force grows at the rate $n$. In this case,

$\frac{I}{K}=n+\delta$

$q=\psi(n+\delta)$

and Eqs. (28), (18)-(22) and (5) can be used to solve for capital intensity, employment rates and real wages.

Steady growth with $g \neq n$ may be of greater interest from the perspective of LDCs. Growth paths of this kind become possible if $\beta=1$ and changes in $L_{T} / L$ do not affect the tradable-sector real wage $\left(\phi_{1}=0\right.$ in Eq. (6)). The latter condition may be reasonable when there is a large pool of hidden unemployment. If $g>n$, the condition will eventually be violated, but the economy may show endogenous steady growth for a prolonged period, and the steady growth rate will be related to the real exchange rate, $q=\psi(g+\delta)$.
Steady growth paths with a positive growth rate do not exist if there are diminishing returns to labor in the non-tradable sector and no technical change. With these assumptions, however, the model has a long-run stationary state if the total labor supply $L$ is given. In this stationary state we have

$\frac{I}{K}=\delta$

where $\delta$ is the rate of depreciation and, using Eqs. (27) and (31), the steady-state value of the real exchange rate is given by

$q=\psi(\delta)$

Using (28), the investment incentives $(\gamma)$ now determine the ratio $\frac{K}{L}$ and hence the capital stock, if $L$ is taken as exogenously given. With the capital stock and the exchange rate fixed, Eqs. (20)-(23) can be used to find non-tradable employment, output and wages, while outcomes in the tradable sector are given by (18)-(19). An increase in $\gamma$ pushes up both total output and employment, but full employment (or inflation barriers) sets an upper limit. This upper limit can be found as in Section 3.4 below, but in the absence of a well-defined, structural NAIRU, a range of employment outcomes may be feasible.

\subsection{Zero sum game?}

In this model the pursuit of faster growth through an appropriate combination of real exchange rates and investment incentives does not imply a zero sum game: the gains of a fast-growing country are not necessarily offset by losses in other countries. A stylized two country model can be used to demonstrate this.

The home country is described by the model in Section 2 . We now supplement this with a simple specification of the "rest of the world" (ROW). We assume that ROW can produce either investment goods or the tradable consumption good, using the same production process. Thus,

$Y_{K}^{*}+Y_{T}^{*}=F\left(L^{*}, K^{*}\right)$

This specification of production possibilities implies that $p_{K}=p_{T}$, assuming that both types of goods are produced in ROW. Subject to this constraint, the home country can exchange its tradable good one-for-one for investment goods. ROW neither gains nor loses from this trade, and the accumulation rate in the home economy (and the associated real exchange rate) has no impact on ROW.

This result should not be surprising. Growth in our open economy is not export-led. Our open economy with $T B=0$ is isomorphic to a closed economy in which the modern sector (corresponding to the tradable sector) produces an output that can be used either for investment or for consumption. With given investment demand and a given supply of modern sector output, the equilibrium condition for the modern sector determines the relative price (corresponding to the real exchange rate), and aggregate employment and output can now be determined in this closed economy.

Needless to say, it is not our claim that domestic policies never have welfare effects in other countries. Growth 
policies, however, need not have negative externalities for the rest of the world.

\subsection{The role of unemployment and the full employment ceiling}

The growth policies in this paper are predicated on the existence of unemployment. This raises two questions for the applicability of the model.

The set of solutions, first, must satisfy a full employment constraint. Using (18) and (21), this constraint can be written

$L_{N}(q, K, s)+L_{T}(K) \leq L$

For a given value of $L$, this equation defines a maximum, full-employment value of the real exchange rate

$q \leq q^{\max }=h(K, s) ; \quad h_{K}<0, h_{s}>0$

The presence of large amounts of (hidden) un- and underemployment suggests that this condition fails to be binding in most LDCs. Using (26), however, it is readily seen that the maximum value of the real exchange rate translates into a maximum growth rate of the capital stock. As the capital stock increases (relative to the population) the maximum values of the real exchange rate and the associated growth rate both decline. Putting it differently, an undervalued exchange rate and fast capital accumulation ceases to be desirable when the capital stock is large relative to the size of the total labor force and the pool of unemployment (and underemployment) dries up. This property of the model is consistent with empirical findings: the relation between undervaluation and growth holds only for developing countries (see Sections 1 and 5).

A second question concerns the potential role of market forces in securing full employment. The presence of unemployment may lead to downward pressure on money wages and with a given world market price of traded goods and a given nominal exchange rate, a reduction in money wages translates into a real depreciation. Thus, with flexible labor markets there would seem to be no need for exchange rate policy: a flexible money wage should take the economy to a full employment position with $q=q^{\max }$.

The benefits of increased money wage flexibility can be questioned - the classic argument was outlined by Keynes (1936) and Fisher (1933) - but it is beyond the scope of the present paper to discuss these issues in any detail. For present purposes it is sufficient to note that as a factual matter, nominal wages do not appear to fall in economies with large amounts of hidden and open unemployment and under these circumstances exchange rate policy becomes important. ${ }^{14}$

In the presence of nominal wage stickiness, adopting a floating exchange rate regime may be considered an alternative solution to achieve full employment. The empirical evidence on nominal exchange rate behavior, however, casts serious doubts in this regard. The disconnect of nominal exchange rate movements from macroeconomic

\footnotetext{
${ }^{14}$ It should be noted perhaps that an extremely high value of the real
}

fundamentals in the short- and medium-run is a well established phenomenon. ${ }^{15}$ Thus, the exchange rate adjustment that is required to mobilize unemployed workers may not automatically occur and, when it does, it may take the form of a sharp depreciation in the wake of a balance of payment crisis.

\section{Short-run dynamics}

At least three assumptions need to be relaxed if the model is to be applied to the short run: export demand is not perfectly elastic, capital in the modern sector is not always fully utilized, and net exports are not always zero. With respect to exports, we assume that the level is predetermined at any moment but that the growth of exports depends on the international competitiveness of the domestically produced export good

$\hat{X}=F\left(\frac{p_{T}}{p_{T}^{*}}\right) ; \quad F^{\prime}<0$

where $p_{T}^{*}$ is the (foreign currency) price of the foreign goods and $a{ }^{\wedge} \wedge$ ' over a variable is used to denote a growth rate $(\hat{X}=(d X / d t) / X)$. The relation between the terms of trade and the relative price $q$ is given by

$\frac{p_{T}}{p_{T}^{*}}=\frac{e p_{T}}{p_{N}} \frac{p_{N}}{e p_{T}^{*}}=q / z$

where $z=e p_{T}^{*} / p_{N}$. We take $z$ to be a policy variable. The domestic currency price of the domestically produced tradable good $\left(e p_{T}\right)$, on the other hand, depends on demand conditions. A simple specification along the lines suggested by Flaschel and Skott (2006) relates changes in the price markup to the rate of utilization:

$\hat{e}+\hat{p}_{T}=\hat{w}_{T}+\lambda(u-\bar{u})$

where $u$ and $\bar{u}$ are the actual and desired capital utilization rates in the tradable sector. We simplify the wage specification for the tradable sector by assuming that the real wage is constant in terms of non-tradables

$\omega_{T}=\frac{w_{T}}{p_{N}}=\bar{\omega}$

This assumption implies that $\hat{w}_{T}=\hat{p}_{N}$, and we get the following expression for the growth rate of $q$,

$\hat{q}=\hat{e}+\hat{p}_{T}-\hat{p}_{N}=\lambda(u-\bar{u})$

exchange rate may be required to achieve full employment. If the real exchange rate and thereby the ratio of non-tradable to tradable goods in the consumption bundle moves beyond a certain point, the gross substitutability assumption in Eq. 9 may cease to hold. When that happens, a further increase in the real exchange rate reduces the rate of accumulation that is consistent with balance of payments equilibrium.

A better route to higher employment without adverse consequences for the balance of payments or the rate of accumulation would be to introduce reforms that shift income in the traditional sector from profits (rent) to wages. Korean and Taiwanese land reforms in the late 1940s and early 1950 s may exemplify shifts of this kind. In terms of the model, a rise in $v \beta$ stimulates employment but leaves the trade balance unaffected (Eqs. (21) and (24)).

15 See, for example, the literature following Meese and Rogoff (1983), which showed that a range of macroeconomic models were unable to beat a random walk in forecasting the behavior of nominal exchange rates. 

by

The utilization rate in the tradable sector is determined

$$
\begin{aligned}
u & =\frac{Y_{T}}{\bar{b} K}=\frac{X+E_{T}}{\bar{b} K}=\frac{X}{\bar{b} K}+(1-\alpha)(1-s)\left[u-\frac{\bar{\omega} L_{T}}{q \bar{b} K}+(1-v \beta) \frac{Y_{N}}{q \bar{b} K}\right] \\
& =\frac{X}{\bar{b} K}+(1-\alpha)(1-s) u\left\{1-(1-\pi)+\left[\frac{\alpha(1-s)}{(1-\alpha(1-s))}+(1-\pi)\right]\right\}
\end{aligned}
$$

or

$u=\frac{1-\alpha(1-s)}{s} \frac{X}{\bar{b} K}=h(q) \frac{X}{K} ; h^{\prime}<0$

where $\pi\left(=\frac{e p_{T} Y_{T}-w_{T} L_{T}}{e p_{T} Y_{T}}=1-\frac{1}{a} \frac{\bar{\omega}}{q}\right)$

is the profit share and the sign of $h^{\prime}$ follows from the assumption of gross substitutability. The profit rate, a key determinant of accumulation, is given by

$r=\pi \frac{p_{T} Y_{T}}{p_{K} K}=\pi u \frac{p_{T}}{p_{K}} \bar{b}=\pi u \frac{p_{T}^{*}}{p_{K}} \frac{q \bar{b}}{z}$

Using (41) and (42) the accumulation function(15) can now be written

$$
\begin{aligned}
\hat{K} & =\frac{I}{K}-\delta \\
& =g(u, q ; \gamma, z)-\delta ; \quad g_{u}>0, g_{q}>0, g_{\gamma}>0, g_{z}<0
\end{aligned}
$$

and, combining (36) and (43), we have

$\hat{X}-\hat{K}=F\left(\frac{q}{z}\right)-g(u, q ; \gamma, z)+\delta$

Given $\gamma$ and $z$, Eqs. (40) and (44) form a two dimensional system of differential equations in $((X / K), q)$. There is a unique (non-trivial) stationary point and the Jacobian is given by

$J\left(\frac{X}{K}, q\right)=\left[\begin{array}{ll}-g_{u} h & \frac{1}{z} F^{\prime}-g_{u} h^{\prime} \frac{X}{K}-g_{q} \\ \lambda h & \lambda h^{\prime} \frac{X}{K}\end{array}\right]$

The determinant and trace are positive and negative, respectively, and the stationary point is (locally asymptotically) stable. The utilization rate is equal to the desired rate at the stationary point, but the stationary solution depends on the policy variables $\gamma$ and $z$, and the trade balance need not be zero if $\gamma$ and $z$ are set independently.

Fig. 1 illustrates the dynamics. The $\hat{q}=0$ locus is upward sloping while the $(\widehat{X / K})=0$ locus can be either negatively or positively sloped; in the latter case it is steeper than the $\hat{q}=0$ locus. An increase in $z$ (a real depreciation) leaves the $\hat{q}=0$ locus unchanged but shifts the $(\widehat{X / K})=0$ locus upwards. Thus, starting from an arbitrary point in the phase diagram (i.e. allowing $u \neq \bar{u}$ ) a real depreciation raises the growth rate of exports and this generates (possibly with a delay) an increase in the accumulation rate: the new stationary point has a higher value of $q$ and an unchanged value of $u$, and from the accumulation function it therefore follows that the system converges to a stationary point with a higher accumulation rate. The utilization rate initially falls but then increases again as it moves toward the (unchanged) desired rate.

An increase in $\gamma$ also raises the accumulation rate. The $(\widehat{X / K})=0$ locus shifts down and the new solution involves a lower export-capital ratio. Thus, a depreciation and an increase in the investment incentive have similar effects on the accumulation rate, but the implications for the trade balance are quite different. We have

$\frac{T B}{K}=p_{T} \frac{X}{K}-p_{K}(\hat{K}+\delta)$

At a stationary point $\hat{X}=\hat{K}=g$ and $p_{T}=p_{T}(g)$. Hence,

$\frac{T B}{K}=p_{T}(g) \frac{X}{K}-p_{K}(g+\delta)$

An increase in $g$ reduces the trade balance, and if the stimulus comes from an increase in $\gamma$, this effect is reinforced by a decline in the export-capital ratio. If the stimulus comes from a real depreciation, however, the deterioration may be offset by an increase in the export-capital ratio.

\section{Empirics}

\subsection{Empirical model}

Our theoretical model predicts a positive relationship between the degree of exchange rate undervaluation and the rate of capital accumulation in countries that have widespread underemployment and are heavily reliant on imported capital goods; traits that are characteristic mainly of developing countries. Fig. 2 illustrates the relationship between undervaluation, accumulation, and output growth for China in a striking manner. We now explore this prediction econometrically, and for a large data set.

Lacking reliable and consistent panel data for the capital stock, we rewrite the accumulation equation to get an expression for the average rate of growth of investment (GROWTHGFCF). Using Eq. (43), we have

$\frac{I}{K}=g(u, q ; \gamma, z)$

or,

$\ln I=\ln K+\ln g(u, q ; \gamma, z)$

The values of $u$ and $q$ converge to stationary points determined by $(\gamma, z)$. With fast convergence, the average values of $u$ and $q$ over a discrete period will be determined largely by the contemporary values of $(\gamma, z)$; more generally, both

$q$

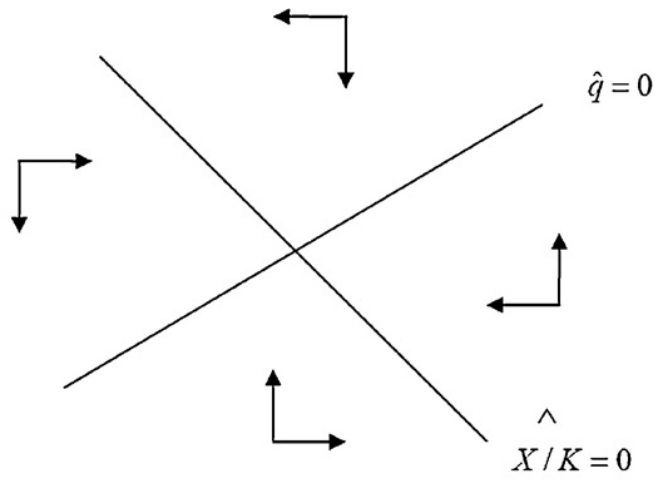

$X / K$

Fig. 1. Phase diagram for the short-run set-up. 


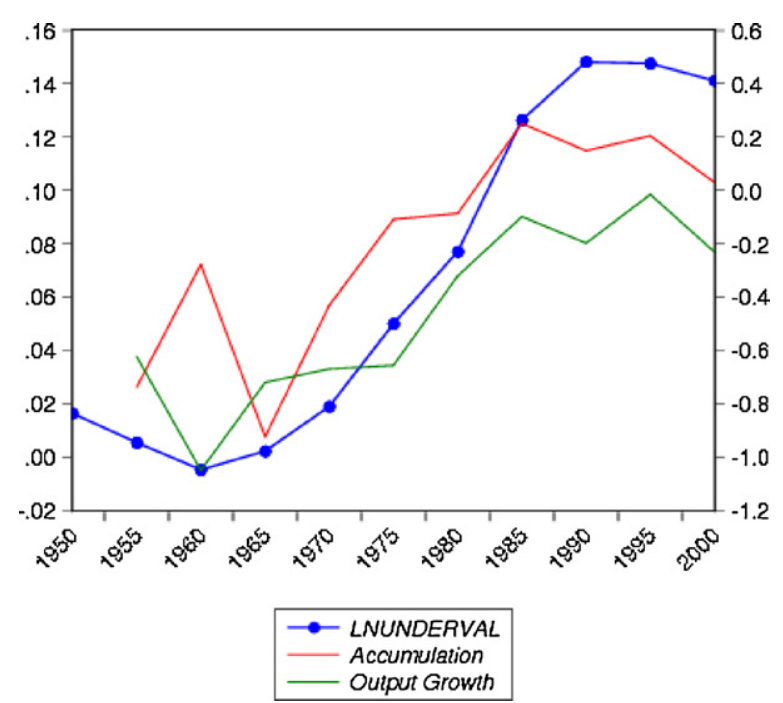

Fig. 2. Time plots of 5-year averaged undervaluation (right hand scale), output growth, and accumulation rate for China (1952-2004).

Source: PWT 6.2, Wang and Szirmai (2008), and authors' calculations.

contemporary and lagged values of $(\gamma, z)$ will affect $u$ and $q$. Thus, Eq. (47) suggests the following discrete-time version of the investment equation

$\ln I=\ln K+\ln H\left(\gamma, \gamma_{-1}, \ldots \gamma_{-n}, z, z_{-1}, \ldots, z_{-n}\right)$

Taking first differences, this investment equation implies that

$$
\begin{aligned}
\Delta \ln I & =\Delta \ln K+\Delta \ln H\left(\gamma, \gamma_{-1}, \ldots \gamma_{-n}, z, z_{-1}, \ldots, z_{-n}\right) \\
& =\frac{I_{-1}}{K_{-1}}+\Delta \ln H\left(\gamma, \gamma_{-1}, \ldots \gamma_{-n}, z, z_{-1}, \ldots, z_{-n}\right) \\
& =G\left(\gamma, \gamma_{-1}, \ldots \gamma_{-n}, \gamma_{-(n+1)}, z, z_{-1}, \ldots, z_{-n}, z_{-(n+1)}\right)
\end{aligned}
$$

We use the degree of undervaluation as an indicator of the $z$ variable and include a range of variables to control for the general investment/growth environment (corresponding here to the current and lagged values of $\gamma$ ). Thus, using a linear approximation and setting $n=1$, we estimate equations of the form

$$
\begin{aligned}
\text { GROWTHGFCF }_{i t}= & \alpha+\beta_{0} \ln R_{\text {RDPCH }}{ }_{i t-1}+\delta_{0} \ln U N D E R V A L_{i t} \\
& +\delta_{1} \ln U N D E R V A L_{i t-1}+\delta_{2} \ln U N D E R V A L_{i t-2} \\
& +\rho X_{t}+f_{t}+f_{i}+\varepsilon_{i t}
\end{aligned}
$$

We follow the three-step methodology pursued by Rodrik (2008) to obtain an index of real exchange rate undervaluation, i.e., UNDERVAL (see Appendix C for more details). The dependent variable is the average annual rate of investment growth, $\mathrm{RGDPCH}_{i-1}$ captures the convergence term, $f_{t}$ time specific effects, $f_{i}$ country specific effects, $\varepsilon_{i t}$ is the error term, and $X$ is a vector of standard control variables, which includes government consumption, the inflation rate, gross domestic savings, ${ }^{16}$ degree of openness, human capital (years of education), terms of

\footnotetext{
16 Since both our model and casual empiricism suggest that the saving rate is affected by the real exchange rate, UNDERVAL and the saving
}

trade, foreign debt, real exchange rate volatility, and an index of rule of law. Table 1 lists the variable definitions and data sources.

The long-run effect of a persistent increase in undervaluation (the sum of the $\delta$-coefficients) is expected to be positive, but the existence of lags implies that the individual $\delta$-coefficients cannot be signed unambiguously by the model. ${ }^{17}$

\subsection{Econometric estimates}

We conducted a series of panel data regressions for a data set of a maximum of 153 countries and up to nine 5-year time periods spanning $1960-2004 .^{18}$ The average annual rate of investment growth (GROWTHGFCF) is calculated from the gross fixed capital formation (GFCF) series obtained from the World Bank's World Development Indicators. Ideally, one would want to include lags of the controls. Since many of the controls are only available for shorter periods, however, there would be a high cost in terms of degrees of freedom.

Table 2 reports results from the estimation of Eq. (50) for the whole sample with different combinations of control variables. The table reports the individual estimates of coefficients on $\ln U N D E R V A L\left(\delta_{i}\right)$ and also its long-run effect, along with the associated Wald statistic for the test of joint significance $\sum_{i=0}^{2} \hat{\delta}_{i}=0$. In columns $1-5$, the coefficient

rate (GDSGDP) are likely to be highly collinear. To correct for multicollinearity, we estimated the effect of undevaluation on the saving rate $\left(G D S G D P=\alpha+\beta \ln U N D E R V A L_{i t}+f_{t}+f_{i}+\varepsilon_{i t}\right)$ and then used the residuals of this regression as a control variable. With this methodology the coefficient on In UNDERVAL captures its direct effect on the dependent variable (GROWTH) and its indirect effect through the saving rate. The coefficient on the residuals captures the effect of the saving rate on the dependent variable, net of the effect of $\ln U N D E R V A L$.

17 The first-order approximation of (49) at a stationary point $\left(\underline{\gamma}^{*}, \underline{z}^{*}, \underline{\dot{\gamma}}^{*}, \underline{\dot{z}}^{*}\right)=\left(\underline{\gamma}^{*}, \underline{z}^{*}, \underline{0}, \underline{0}\right)$ can be written

$$
\begin{aligned}
\Delta \ln I= & \alpha+\sum_{i=0}^{n} H_{\gamma_{-i}}\left(\underline{\gamma}^{*}, \underline{z}^{*}\right) \gamma_{-(i+1)}+\sum_{i=0}^{n} H_{z_{i}}\left(\underline{\gamma^{*}}, \underline{z}^{*}\right) z_{-(i+1)} \\
& +\sum_{i=0}^{n} \frac{H_{\gamma_{-i}}}{H}\left(\gamma_{-i}-\gamma_{-(i+1)}\right)+\sum_{i=0}^{n} \frac{H_{z_{-i}}}{H}\left(z_{-i}-z_{-(i+1)}\right. \\
= & \alpha \frac{H_{\gamma}}{H} \gamma+\frac{H_{z}}{H} z+\sum_{i=0}^{n-1}\left(H_{\gamma_{-(i+1)}}+\frac{H_{\gamma_{-(i+1)}}-H_{\gamma_{-i}}}{H}\right) \gamma_{-(i+1)} \\
& +\sum_{i=0}^{n-1}\left(H_{z_{-(i+1)}}+\frac{H_{z_{-(i+1)}}-H_{z_{-i}}}{H}\right) z_{-(i+1)} \\
& +\left(H_{\gamma_{-n}}-\frac{H_{\gamma_{-n}}}{H}\right) \gamma_{-(n+1)} \\
& +\left(H_{z_{-n}}-\frac{H_{z_{-n}}}{H}\right) z_{-(n+1)}
\end{aligned}
$$

With 5-year periods, each estimated coefficient may be a weighted average of some of the coefficients in the above equation and cannot be unambiguously signed. The long-run effect of a persistent change in undervaluation, however, is given by $\sum H_{z_{-i}}>0$.

18 We exclude from the sample extreme values of the undervaluation index from the sample $(-1.5>\ln U N D E R V A L>1.5)$. This involves excluding a maximum of 15 data points. 
Table 1

Data definitions, sources, and coverage.

\begin{tabular}{|c|c|c|c|c|}
\hline Name & Code & Definition & Source & Coverage \\
\hline Investment growth & GROWTHGFCF & $G R O W T H G F C F=\left[\left(G F C F_{t} / G F C F_{t-1}\right)^{0.2}\right]-1$ & Authors' calculations & $1965-2004$ \\
\hline Real Exchange Rate & RER & $R E R=X R A T / P P P$ & Authors' calculations & 1950-2004 \\
\hline Real Exchange Rate Volatility & RERVOL & $\begin{array}{l}\text { Calculated as the coefficient of } \\
\text { variation of RER within each } 5 \text {-year } \\
\text { period. }\end{array}$ & Authors' calculations & $1960-2004$ \\
\hline Average years of education & TYR & $\begin{array}{l}\text { Average years of education for the } \\
\text { population aged } 25 \text { and over. }\end{array}$ & Barro and Lee (2000) & 1960-1999 \\
\hline Rule of Law Index & $R O L$ & $\begin{array}{l}\text { Index elaborated based on responses } \\
\text { on the quality of governance given by a } \\
\text { large number of enterprise, citizen and } \\
\text { expert survey. It is measured in units } \\
\text { ranging from about }-2.5 \text { to } 2.5 \text {, with } \\
\text { higher values corresponding to better } \\
\text { governance outcomes. }\end{array}$ & Kaufmann et al. (2008) & $1996-2004$ \\
\hline Real GDP per capita & RGDPCH & $\begin{array}{l}\text { Real GDP per capita in constant U.S. } \\
\text { dollars in } 2000 . \text { It is obtained using a } \\
\text { chain index. }\end{array}$ & PWT & 1950-2004 \\
\hline Nominal Exchange Rate & $X R A T$ & National currency units per U.S. dollar. & PWT & 1950-2004 \\
\hline Degree of Openness & OPENC & $\begin{array}{l}\text { Exports plus Imports divided by GDP. } \\
\text { All variables are expressed in current } \\
\text { prices. }\end{array}$ & PWT & 1960-2004 \\
\hline Purchasing Power Parity & $P P P$ & $\begin{array}{l}\text { Number of national currency units } \\
\text { required to buy goods equivalent to } \\
\text { what can be bought with one unit of } \\
\text { U.S. It is calculated over GDP }\end{array}$ & PWT & $1950-2004$ \\
\hline Gross Domestic Savings & GDSGDP & $\begin{array}{l}\text { Gross domestic savings is calculated as } \\
\text { GDP less final consumption } \\
\text { expenditure (total consumption). Data } \\
\text { are as share of GDP and divided by } 100 \text {. }\end{array}$ & WDI & $1960-2004$ \\
\hline Government Consumption & GOVGDP & $\begin{array}{l}\text { It includes all government current } \\
\text { expenditures for purchases of goods } \\
\text { and services. Data are as share of GDP } \\
\text { and divided by } 100 .\end{array}$ & WDI & 1960-2004 \\
\hline Consumer Price Index & CPI & Consumer price index. & WDI & 1960-2004 \\
\hline Investment (Gross Fixed Capital Formation) & GFCF & $\begin{array}{l}\text { It includes land improvements; plant, } \\
\text { machinery, and equipment purchases; } \\
\text { and the construction (including } \\
\text { schools, roads, railways, offices, } \\
\text { hospitals, private residential } \\
\text { dwellings). Data are in constant local } \\
\text { currency. }\end{array}$ & WDI & 1960-2004 \\
\hline External debt & DEBTGNI & $\begin{array}{l}\text { Total external debt stocks to gross } \\
\text { national income. }\end{array}$ & WDI & 1960-2004 \\
\hline Terms of Trade & $T T$ & $\begin{array}{l}\text { The terms of trade effect equals } \\
\text { capacity to import less exports of } \\
\text { goods and services in constant prices. } \\
\text { Data are in constant local currency. }\end{array}$ & WDI & 1960-2004 \\
\hline
\end{tabular}

on $\ln U N D E R V A L_{t-1}$ is significant at $1 \%$ and stable in the range $0.042-0.051$. This would suggest that some time is needed for a competitive currency to stimulate investment decisions. The current effect of $\ln U N D E R V A L$ is slightly negative (between -0.002 and -0.017 ) and insignificant, whereas the twice lagged coefficient is negative, varies between -0.015 and -0.027 and is significant at either $5 \%$ or $10 \%$, except for the baseline equation where it is not significant. When we consider the overall long-run effect of undervaluation on investment growth, we observe that it tends to be small and statistically insignificant, except for the baseline equation in which it is moderately large (0.023) and the Wald test indicates significance at $10 \%$. In the regressions that include the terms of trade and the rule of law index (columns 6 and 7, respectively) ln UNDERVAL and its lags are not significant either individually or jointly. This appears to be due to the decline in the degrees of freedom available. ${ }^{19}$ Column 8 reports the regression in which $\ln U N D E R V A L$ interacts with the level of GDP per capita. The negative sign on the interaction term indicates that as income per capita increases the effect of $\ln U N D E R V A L$ decreases. According to the estimated coefficients, the long-run effect of undervaluation becomes nil at a level of GDP per capita around $\$ 8800$. Thus, the positive effect of

\footnotetext{
19 When we run regression (4) in Table 2 using the same subsamples as in regressions (6) and (7) but excluding terms of trade and the rule of law index, we obtained similarly insignificant results.
} 
Table 2

Panel evidence on investment growth (all countries: 1960-2004).

\begin{tabular}{|c|c|c|c|c|c|c|c|c|}
\hline Dependent variable: GROWTHGFCF (investment g & $\begin{array}{l}\text { rowth })^{\mathrm{a}, b} \\
\text { (1) } \\
\text { Baseline }\end{array}$ & $(2)$ & (3) & $(4)$ & $(5)$ & $(6)$ & (7) & $(8)$ \\
\hline Ln $\mathrm{RGDPCH}_{t-1}$ & $\begin{array}{l}-0.071^{\text {**** }} \\
(-5.65)\end{array}$ & $\begin{array}{l}-0.070^{* * *} \\
(-4.90)\end{array}$ & $\begin{array}{l}-0.087^{* * *} \\
(-5.96)\end{array}$ & $\begin{array}{l}-0.097^{* * *} \\
(-6.49)\end{array}$ & $\begin{array}{l}-0.110^{* * *} \\
(-5.81)\end{array}$ & $\begin{array}{l}-0.110^{* * *} \\
(-5.09)\end{array}$ & $\begin{array}{l}-0.162^{* *} \\
(-2.29)\end{array}$ & $\begin{array}{l}-0.080^{* * *} \\
(-6.36)\end{array}$ \\
\hline Ln UNDERVAL $L_{t}$ & $\begin{array}{l}-0.006 \\
(-0.51)\end{array}$ & $\begin{array}{l}-0.002 \\
(-0.12)\end{array}$ & $\begin{array}{l}-0.013 \\
(-0.99)\end{array}$ & $\begin{array}{l}-0.014 \\
(-1.08)\end{array}$ & $\begin{array}{l}-0.017 \\
(-1.19)\end{array}$ & $\begin{array}{l}-0.009 \\
(-0.49)\end{array}$ & $\begin{array}{l}0.040 \\
(0.78)\end{array}$ & $\begin{array}{l}0.107^{* * *} \\
(3.30)\end{array}$ \\
\hline Ln $U N D E R V A L_{t-1}$ & $\begin{array}{l}0.044^{* * * *} \\
(3.24)\end{array}$ & $\begin{array}{l}0.042^{* * *} \\
(2.94)\end{array}$ & $\begin{array}{l}0.042^{* * * *} \\
(3.00)\end{array}$ & $\begin{array}{l}0.042^{* * * *} \\
(3.00)\end{array}$ & $\begin{array}{l}0.051^{* * *} \\
(3.42)\end{array}$ & $\begin{array}{l}0.029 \\
(1.64)\end{array}$ & $\begin{array}{l}0.003 \\
(0.08)\end{array}$ & $\begin{array}{l}0.153^{* * * *} \\
(4.80)\end{array}$ \\
\hline Ln UNDERVAL $L_{t-2}$ & $\begin{array}{l}-0.015 \\
(-1.27)\end{array}$ & $\begin{array}{l}-0.025^{* *} \\
(-2.12)\end{array}$ & $\begin{array}{l}-0.021^{*} \\
(-1.81)\end{array}$ & $\begin{array}{l}-0.023^{*} \\
(-1.94)\end{array}$ & $\begin{array}{l}-0.027^{*} \\
(-1.93)\end{array}$ & $\begin{array}{l}-0.022 \\
(-1.38)\end{array}$ & $\begin{array}{l}0.034 \\
(1.18)\end{array}$ & $\begin{array}{l}0.101^{* * * *} \\
(3.09)\end{array}$ \\
\hline Government Consumption (share of GDP) & & $\begin{array}{l}0.141 \\
(1.41)\end{array}$ & $\begin{array}{l}0.148 \\
(1.51)\end{array}$ & $\begin{array}{l}0.224^{* *} \\
(2.21)\end{array}$ & $\begin{array}{l}0.295^{* *} \\
(2.55)\end{array}$ & $\begin{array}{l}0.181 \\
(1.32)\end{array}$ & $\begin{array}{l}0.299 \\
(0.94)\end{array}$ & \\
\hline $\operatorname{Ln}\left(\mathrm{CPI}_{t} / \mathrm{CPI}_{t-1}\right)$ & & $\begin{array}{l}-0.010^{* * *} \\
(-3.88)\end{array}$ & $\begin{array}{l}-0.009^{* * *} \\
(-3.61)\end{array}$ & $\begin{array}{l}-0.009^{* * *} \\
(-3.58)\end{array}$ & $\begin{array}{l}-0.008^{* * *} \\
(-2.70)\end{array}$ & $\begin{array}{l}-0.007^{* *} \\
(-2.50)\end{array}$ & $\begin{array}{l}0.016 \\
(0.79)\end{array}$ & \\
\hline Ln (RER volatility) & & $\begin{array}{l}-0.009^{* *} \\
(-2.53)\end{array}$ & $\begin{array}{l}-0.009^{* *} \\
(-2.57)\end{array}$ & $\begin{array}{l}-0.009^{* *} \\
(-2.55)\end{array}$ & $\begin{array}{l}-0.011^{* * *} \\
(-2.90)\end{array}$ & $\begin{array}{l}-0.015^{* * *} \\
(-3.10)\end{array}$ & $\begin{array}{l}0.003 \\
(0.34)\end{array}$ & \\
\hline Openness (Exports +Imports as share of GDP) & & & $\begin{array}{l}0.084^{* * *} \\
(4.31)\end{array}$ & $\begin{array}{l}0.077^{* * *} \\
(3.91)\end{array}$ & $\begin{array}{l}0.101^{* * *} \\
(3.79)\end{array}$ & $\begin{array}{l}0.048^{*} \\
(1.82)\end{array}$ & $\begin{array}{l}0.019 \\
(0.32)\end{array}$ & \\
\hline Gross Domestic Saving (Residuals) & & & & $\begin{array}{l}0.137^{* * * *} \\
(2.81)\end{array}$ & $\begin{array}{l}0.202^{* * *} \\
(3.57)\end{array}$ & $\begin{array}{l}0.166^{* *} \\
(2.31)\end{array}$ & $\begin{array}{l}-0.010 \\
(-0.06)\end{array}$ & \\
\hline Average years of education & & & & & $\begin{array}{l}-0.005 \\
(-0.75)\end{array}$ & & & \\
\hline Ln Terms of Trade & & & & & & $\begin{array}{l}-0.019 \\
(-0.98)\end{array}$ & & \\
\hline Rule of Law & & & & & & & $\begin{array}{l}0.070^{* *} \\
(2.58)\end{array}$ & \\
\hline $\operatorname{Ln}(\mathrm{RGDPCH}) \times\left(\operatorname{LnUND}_{t}+\operatorname{LnUND}_{t-1}+\operatorname{LnUND}_{t-2}\right)$ & & & & & & & & $\begin{array}{l}-0.013^{* * *} \\
(-3.82)\end{array}$ \\
\hline Time Dummies & Yes & Yes & Yes & Yes & Yes & Yes & Yes & Yes \\
\hline Country Dummies & Yes & Yes & Yes & Yes & Yes & Yes & Yes & Yes \\
\hline $\operatorname{LnUND}_{t}+\operatorname{LnUND}_{t-1}+\operatorname{LnUND}_{t-2}$ & 0.023 & 0.015 & 0.008 & 0.005 & 0.007 & -0.002 & 0.077 & - \\
\hline Wald statistic & 3.196 & 1.238 & 0.335 & 0.141 & 0.187 & 0.005 & 1.045 & - \\
\hline p-value & $(0.074)$ & $(0.266)$ & $(0.563)$ & $(0.708)$ & $(0.666)$ & $(0.942)$ & $(0.307)$ & - \\
\hline Adjusted R-squared & 0.18 & 0.22 & 0.25 & 0.26 & 0.33 & 0.19 & 0.22 & 0.20 \\
\hline Number of countries & 153 & 138 & 138 & 138 & 90 & 102 & 131 & 153 \\
\hline Observations & 712 & 639 & 639 & 639 & 432 & 395 & 234 & 712 \\
\hline
\end{tabular}

a ${ }^{*} p<0.10,{ }^{* *} p<0.05,{ }^{* * *} p<0.01$.

b All regressions exclude observations for which $\operatorname{Ln}(U N D E R V A L)<-1.5$ and $\operatorname{Ln}(U N D E R V A L)>1.5$.

undervaluation on investment growth appears to operate particularly for developing countries. ${ }^{20}$

In order to investigate differences among countries at different levels of income, we first used a relatively standard classification in defining developed countries as a group of 23 countries typically considered industrialized. ${ }^{21}$ We refer to this as "Classification I." One potential objection to this classification is its static nature: countries are classified as either developed or developing based on their current status. In our sample period that covers 45 years, it is not evident that a country that is now seen as developed would have been considered the same at the beginning of the sample. Some European countries in the immediate post-war period come to mind in this regard. Similarly, there might be developing countries today which could have been considered developed at the beginning of the

\footnotetext{
${ }^{20}$ We also tried non-linear specifications but found the quadratic interaction term to be insignificant.

${ }^{21}$ The countries are Australia, Austria, Belgium, Canada, Denmark, Finland, France, Germany, Greece, Iceland, Ireland, Italy, Japan, Luxemburg, Netherlands, New Zeland, Norway, Portugal, Spain, Sweden, Switerland, United Kindom and United States. Other studies have followed a similar classification. See, for example, Prasad et al. (2007).
}

sample. An example is Argentina. In order to provide a more dynamic classification of countries, our second classification, termed "Classification II," defines developed countries as those which in a given 5 -year period were at a per capita GDP level at least half that of the US, excluding those that had a population of less than a million in 2004. Under this classification, some countries are defined as developed (developing) at the beginning but not at the end of the sample. As a further robustness test, we follow Rodrik (2008) and others by classifying countries based on their per capita income; under Classification III, countries with a per capital real GDP below $\$ 6,000$ (in constant 2000 dollars) are classified as developing and the rest as developed. In the remainder of this section, we focus on the results from Classification I, only briefly reporting results for the other classifications for comparison. The detailed results for Classifications II and III, which are largely similar, are reported in a separate available-on-request appendix.

Tables 3 and 4 provide further evidence that the effect of undervaluation on investment growth is particularly important for developing countries (as defined under Classification I). Table 3 reports the fixed effect regressions for developing countries. The long-run effect of undervaluation is large, significant and robust to various controls. 
Table 3

Panel evidence on investment growth (developing countries, classification I: 1960-2004).

\begin{tabular}{|c|c|c|c|c|c|c|c|c|c|}
\hline Dependent variable: GROWTHGFCF & $\begin{array}{l}\text { investment } \\
\text { (1) } \\
\text { Baseline }\end{array}$ & $\begin{array}{l}\text { growth })^{\mathrm{a}, b} \\
(2)\end{array}$ & (3) & $(4)$ & $(5)$ & (6) & $(7)$ & $\begin{array}{l}(8) \\
1960-1984\end{array}$ & $\begin{array}{l}(9) \\
1985-2004\end{array}$ \\
\hline Ln $\mathrm{RGDPCH}_{t-1}$ & $\begin{array}{l}-0.083^{* * *} \\
(-5.88)\end{array}$ & $\begin{array}{l}-0.081^{* * *} \\
(-5.01)\end{array}$ & $\begin{array}{l}-0.113^{* * *} \\
(-5.88)\end{array}$ & $\begin{array}{l}-0.124^{* * *} \\
(-6.27)\end{array}$ & $\begin{array}{l}-0.134^{* * *} \\
(-5.17)\end{array}$ & $\begin{array}{l}-0.156^{* * *} \\
(-5.37)\end{array}$ & $\begin{array}{l}-0.181^{* *} \\
(-2.09)\end{array}$ & $\begin{array}{l}-0.168^{* * *} \\
(-3.01)\end{array}$ & $\begin{array}{l}-0.127^{* * *} \\
(-5.55)\end{array}$ \\
\hline Ln UNDERVAL $L_{t}$ & $\begin{array}{l}0.012 \\
(0.86)\end{array}$ & $\begin{array}{l}0.017 \\
(1.14)\end{array}$ & $\begin{array}{l}0.027^{*} \\
(1.70)\end{array}$ & $\begin{array}{l}0.026 \\
(1.63)\end{array}$ & $\begin{array}{l}0.036^{*} \\
(1.69)\end{array}$ & $\begin{array}{l}0.015 \\
(0.81)\end{array}$ & $\begin{array}{l}0.040 \\
(0.68)\end{array}$ & $\begin{array}{l}0.019 \\
(0.53)\end{array}$ & $\begin{array}{l}-0.001 \\
(-0.06)\end{array}$ \\
\hline Ln UNDERVAL $L_{t-1}$ & $\begin{array}{l}0.048^{* * *} \\
(3.18)\end{array}$ & $\begin{array}{l}0.040^{* *} \\
(2.47)\end{array}$ & $\begin{array}{l}0.032^{*} \\
(1.96)\end{array}$ & $\begin{array}{l}0.032^{* *} \\
(1.97)\end{array}$ & $\begin{array}{l}0.023 \\
(1.17)\end{array}$ & $\begin{array}{l}0.048^{* *} \\
(2.50)\end{array}$ & $\begin{array}{l}-0.022 \\
(-0.49)\end{array}$ & $\begin{array}{l}0.092^{* *} \\
(2.13)\end{array}$ & $\begin{array}{l}0.049^{* * *} \\
(2.93)\end{array}$ \\
\hline Ln $U N D E R V A L_{t-2}$ & $\begin{array}{l}0.006 \\
(0.47)\end{array}$ & $\begin{array}{l}0.003 \\
(0.20)\end{array}$ & $\begin{array}{l}0.001 \\
(0.04)\end{array}$ & $\begin{array}{l}-0.000 \\
(-0.02)\end{array}$ & $\begin{array}{l}-0.003 \\
(-0.15)\end{array}$ & $\begin{array}{l}-0.004 \\
(-0.22)\end{array}$ & $\begin{array}{l}0.028 \\
(0.76)\end{array}$ & $\begin{array}{l}0.008 \\
(0.17)\end{array}$ & $\begin{array}{l}0.008 \\
(0.52)\end{array}$ \\
\hline $\begin{array}{l}\text { Government Consumption } \\
\text { (share of GDP) }\end{array}$ & & $\begin{array}{l}0.024 \\
(0.21)\end{array}$ & $\begin{array}{l}0.092 \\
(0.76)\end{array}$ & $\begin{array}{l}0.149 \\
(1.20)\end{array}$ & $\begin{array}{l}0.149 \\
(0.98)\end{array}$ & $\begin{array}{l}0.319^{* *} \\
(2.09)\end{array}$ & $\begin{array}{l}0.211 \\
(0.57)\end{array}$ & & \\
\hline $\operatorname{Ln}\left(\mathrm{CPI}_{t} / \mathrm{CPI}_{t-1}\right)$ & & $\begin{array}{l}-0.010^{* * *} \\
(-3.59)\end{array}$ & $\begin{array}{l}-0.007^{* * *} \\
(-2.61)\end{array}$ & $\begin{array}{l}-0.007^{* * *} \\
(-2.63)\end{array}$ & $\begin{array}{l}-0.007^{* *} \\
(-2.08)\end{array}$ & $\begin{array}{l}-0.006 \\
(-1.61)\end{array}$ & $\begin{array}{l}0.023 \\
(0.96)\end{array}$ & & \\
\hline Ln (RER volatility) & & $\begin{array}{l}-0.015^{* * *} \\
(-3.30)\end{array}$ & $\begin{array}{l}-0.011^{* *} \\
(-2.39)\end{array}$ & $\begin{array}{l}-0.011^{* *} \\
(-2.38)\end{array}$ & $\begin{array}{l}-0.015^{* *} \\
(-2.52)\end{array}$ & $\begin{array}{l}-0.012^{* *} \\
(-2.04)\end{array}$ & $\begin{array}{l}-0.005 \\
(-0.52)\end{array}$ & & \\
\hline $\begin{array}{l}\text { Openness } \\
\text { (Exports + Imports as share of GDP) }\end{array}$ & & & $\begin{array}{l}0.065^{* * *} \\
(2.63)\end{array}$ & $\begin{array}{l}0.060^{* *} \\
(2.42)\end{array}$ & $\begin{array}{l}0.049 \\
(1.60)\end{array}$ & $\begin{array}{l}0.101^{* * *} \\
(2.84)\end{array}$ & $\begin{array}{l}0.030 \\
(0.39)\end{array}$ & & \\
\hline $\begin{array}{l}\text { External Debt } \\
\text { (share of GNI) }\end{array}$ & & & $\begin{array}{l}-0.051^{* * *} \\
(-3.87)\end{array}$ & $\begin{array}{l}-0.050^{* * *} \\
(-3.83)\end{array}$ & $\begin{array}{l}-0.054^{* * *} \\
(-3.43)\end{array}$ & $\begin{array}{l}-0.043^{* *} \\
(-2.53)\end{array}$ & $\begin{array}{l}-0.007 \\
(-0.17)\end{array}$ & & \\
\hline Gross Domestic Saving (Residuals) & & & & $\begin{array}{l}0.136^{* *} \\
(2.16)\end{array}$ & $\begin{array}{l}0.126 \\
(1.55)\end{array}$ & $\begin{array}{l}\mathrm{q} 227^{* * *} \\
(2.78)\end{array}$ & $\begin{array}{l}0.084 \\
(0.43)\end{array}$ & & \\
\hline Ln Terms of Trade & & & & & $\begin{array}{l}-0.015 \\
(-0.71)\end{array}$ & & & & \\
\hline Average years of education & & & & & & $\begin{array}{l}0.002 \\
(0.17)\end{array}$ & & & \\
\hline Rule of Law & & & & & & & $\begin{array}{l}0.087^{* *} \\
(2.61)\end{array}$ & & \\
\hline Time Dummies & Yes & Yes & Yes & Yes & Yes & Yes & Yes & Yes & Yes \\
\hline Country Dummies & Yes & Yes & Yes & Yes & Yes & Yes & Yes & Yes & Yes \\
\hline $\operatorname{LnUND}_{t}+\operatorname{LnUND}_{t-1}+\operatorname{LnUND}_{t-2}$ & 0.066 & 0.060 & 0.060 & 0.058 & 0.056 & 0.059 & 0.046 & 0.118 & 0.056 \\
\hline Wald statistic & 15.79 & 10.94 & 8.85 & 8.37 & 3.86 & 4.80 & 0.27 & 4.90 & 4.43 \\
\hline$p$-Value & $(0.000)$ & $(0.001)$ & $(0.003)$ & $(0.004)$ & $(0.049)$ & $(0.029)$ & $(0.600)$ & $(0.027)$ & $(0.035)$ \\
\hline Adjusted $R$-squared & 0.23 & 0.28 & 0.32 & 0.33 & 0.24 & 0.37 & 0.23 & 0.45 & 0.22 \\
\hline Number of countries & 130 & 115 & 100 & 100 & 76 & 61 & 98 & 65 & 130 \\
\hline Observations & 552 & 484 & 420 & 420 & 294 & 261 & 173 & 166 & 386 \\
\hline
\end{tabular}

a ${ }^{*} p<0.10, p<0.05,{ }^{*} p<0.01$

b All regressions exclude observations for which $\operatorname{Ln}(U N D E R V A L)<-1.5$ and $\operatorname{Ln}(U N D E R V A L)>1.5$.

In columns $1-6$, the estimated long-run coefficient is in the range of $0.056-0.066$. The only case where the coefficient is smaller and not significant is the regression that includes the rule of law index (column 7). Note, however, that undervaluation is not the only variable that loses explanatory power. Most of the control variables that in the previous specifications are highly significant turn insignificant here. Again, this result is likely attributable to the small number of observations available for the rule of law index. ${ }^{22}$

Again, the positive effect of undervaluation on investment growth appears to operate mainly through the first lag. The estimated coefficient for $\delta_{1}$ is always large and significant (except for that in column 7). On the other hand, the current effect of $\ln U N D E R V A L$ is negative and almost always insignificant. Finally, the positive long-run effect of currency undervaluation on investment growth for developing countries is robust to changes in the sample

\footnotetext{
22 This conclusion receives strong support from our finding that all the insignificant control variables continue to be insignificant if we run the regression with the sample of countries that report data for the rule of law index, but exclude the index itself as a control variable.
}

period (columns 8 and 9 ). When we split the sample into two sub-periods (1960-1984 and 1985-2004), the longrun coefficient of $\ln U N D E R V A L$ is significant at $5 \%$ in both periods.

Table 4 shows the results for developed countries. Because of the small number of observations, we introduce control variables individually. The long-run effect of undervaluation is statistically indistinguishable from zero in all the regressions. The estimated coefficient on In UNDERVAL $L_{t-1}$ is large and positive (although not very significant) but is "neutralized" by the negative effects of the current level and second lag. The results using the other classifications, reported in the available-on-request appendix, are qualitatively similar to those in Tables 3 and 4, except for that, with Classification III, the effect of undervaluation on investment growth turns negative for developed countries.

Tables 5-7 report robustness checks of the positive relationship between currency undervaluation and investment growth found for developing countries. Since the real exchange rate is arguably determined jointly with other variables, a potential concern is that the results provided in Table 3 are contaminated by endogeneity/simultaneity problems. To address this issue, we carry 
Table 4

Panel evidence on investment growth (developed countries, classification I: 1960-2004).

\begin{tabular}{|c|c|c|c|c|c|c|c|c|c|c|c|}
\hline Dependent variable: GROWTHGFCF ( & $\begin{array}{l}\text { vestment grc } \\
\text { (1) } \\
\text { Baseline }\end{array}$ & $\begin{array}{l}\text { th })^{a, b} \\
(2)\end{array}$ & (3) & $(4)$ & (5) & (6) & (7) & (8) & (9) & $(10)$ & $(11)$ \\
\hline Ln $\mathrm{EGDPCH}_{t-1}$ & $\begin{array}{l}-0.109^{* * *} \\
(-4.48)\end{array}$ & $\begin{array}{l}-0.107^{* * *} \\
(-4.44)\end{array}$ & $\begin{array}{l}-0.119^{* * *} \\
(-5.38)\end{array}$ & $\begin{array}{l}-0.125^{* * *} \\
(-5.32)\end{array}$ & $\begin{array}{l}-0.107^{* * *} \\
(-4.34)\end{array}$ & $\begin{array}{l}-0.104^{* * *} \\
(-4.29)\end{array}$ & $\begin{array}{l}-0.116^{* * *} \\
(-5.00)\end{array}$ & $\begin{array}{l}-0.121^{* * *} \\
(-5.49)\end{array}$ & $\begin{array}{l}-0.147^{* * *} \\
(-5.02)\end{array}$ & $\begin{array}{l}-0.098^{*} \\
(-1.79)\end{array}$ & $\begin{array}{l}-0.162^{*} \\
(-1.89)\end{array}$ \\
\hline Ln UNDERVAL $L_{t}$ & $\begin{array}{l}-0.019 \\
(-0.63)\end{array}$ & $\begin{array}{l}-0.024 \\
(-0.81)\end{array}$ & $\begin{array}{l}-0.033 \\
(-1.22)\end{array}$ & $\begin{array}{l}-0.049^{*} \\
(-1.68)\end{array}$ & $\begin{array}{l}-0.017 \\
(-0.55)\end{array}$ & $\begin{array}{l}-0.011 \\
(-0.37)\end{array}$ & $\begin{array}{l}-0.042 \\
(-1.46)\end{array}$ & $\begin{array}{l}-0.043 \\
(-1.57)\end{array}$ & $\begin{array}{l}-0.033 \\
(-1.09)\end{array}$ & $\begin{array}{l}-0.092 \\
(-1.77)\end{array}$ & $\begin{array}{l}0.111 \\
(1.25)\end{array}$ \\
\hline Ln $U N D E R V A L_{t-1}$ & $\begin{array}{l}0.056^{*} \\
(1.72)\end{array}$ & $\begin{array}{l}0.043 \\
(1.30)\end{array}$ & $\begin{array}{l}0.050^{*} \\
(1.69)\end{array}$ & $\begin{array}{l}0.064^{* *} \\
(2.06)\end{array}$ & $\begin{array}{l}0.057^{*} \\
(1.70)\end{array}$ & $\begin{array}{l}0.058^{*} \\
(1.78)\end{array}$ & $\begin{array}{l}0.055^{*} \\
(1.77)\end{array}$ & $\begin{array}{l}0.054^{*} \\
(1.82)\end{array}$ & $\begin{array}{l}0.053 \\
(1.58)\end{array}$ & $\begin{array}{l}0.071 \\
(1.50)\end{array}$ & $\begin{array}{l}0.181^{*} \\
(1.89)\end{array}$ \\
\hline Ln $U N D E R V A L_{t-2}$ & $\begin{array}{l}-0.020 \\
(-0.81)\end{array}$ & $\begin{array}{l}-0.012 \\
(-0.48)\end{array}$ & $\begin{array}{l}0.006 \\
(0.28)\end{array}$ & $\begin{array}{l}-0.010 \\
(-0.42)\end{array}$ & $\begin{array}{l}-0.025 \\
(-0.93)\end{array}$ & $\begin{array}{l}-0.023 \\
(-0.91)\end{array}$ & $\begin{array}{l}-0.007 \\
(-0.28)\end{array}$ & $\begin{array}{l}0.007 \\
(0.30)\end{array}$ & $\begin{array}{l}-0.018 \\
(-0.72)\end{array}$ & $\begin{array}{l}-0.039 \\
(0.90)\end{array}$ & $\begin{array}{l}-0.069 \\
(-0.99)\end{array}$ \\
\hline $\begin{array}{l}\text { Government Consumption } \\
\text { (share of GDP) }\end{array}$ & & $\begin{array}{l}-0.283^{*} \\
(-1.91)\end{array}$ & & & & & $\begin{array}{l}-0.251^{*} \\
(-1.70)\end{array}$ & $\begin{array}{l}-0.085 \\
(-0.58)\end{array}$ & & & \\
\hline Gross Domestic Saving (Residuals) & & & $\begin{array}{l}0.233^{* * *} \\
(5.38)\end{array}$ & & & & & $\begin{array}{l}0.177^{* * *} \\
(3.71)\end{array}$ & & & \\
\hline $\begin{array}{l}\text { Openness } \\
\text { (Exports + Imports as share of GDP) }\end{array}$ & & & & $\begin{array}{l}0.087^{* * *} \\
(3.82)\end{array}$ & & & $\begin{array}{l}0.081^{* * *} \\
(3.52)\end{array}$ & $\begin{array}{l}0.054^{* *} \\
(2.36)\end{array}$ & & & \\
\hline Ln (RER volatility) & & & & & $\begin{array}{l}-0.006 \\
(-1.31)\end{array}$ & & & & & & \\
\hline $\operatorname{Ln}\left(\mathrm{CPI}_{t} / \mathrm{CPI}_{t-1}\right)$ & & & & & & $\begin{array}{l}-0.021 \\
(-1.53)\end{array}$ & $\begin{array}{l}-0.029^{* *} \\
(-2.23)\end{array}$ & $\begin{array}{l}-0.020 \\
(-1.58)\end{array}$ & & & \\
\hline Average years of education & & & & & & & & & $\begin{array}{l}-0.008 \\
(-1.52)\end{array}$ & & \\
\hline Ln Terms of Trade & & & & & & & & & & $\begin{array}{l}-0.058 \\
(-1.37)\end{array}$ & \\
\hline Rule of Law & & & & & & & & & & & $\begin{array}{l}0.031 \\
(0.63)\end{array}$ \\
\hline Time Dummies & Yes & Yes & Yes & Yes & Yes & Yes & Yes & Yes & Yes & Yes & Yes \\
\hline Country Dummies & Yes & Yes & Yes & Yes & Yes & Yes & Yes & Yes & Yes & Yes & Yes \\
\hline $\operatorname{LnUND}_{t}+\operatorname{LnUND}_{t-1}+\operatorname{LnUND}_{t-2}$ & 0.017 & 0.007 & 0.023 & 0.005 & 0.015 & 0.024 & 0.007 & 0.018 & 0.002 & -0.060 & 0.222 \\
\hline Wald statistic & 0.61 & 0.11 & 1.41 & 0.05 & 0.46 & 1.19 & 0.10 & 0.79 & 0.001 & 1.09 & 1.84 \\
\hline$p$-Value & $(0.436)$ & $(0.744)$ & $(0.236)$ & $(0.826)$ & $(0.497)$ & $(0.275)$ & $(0.749)$ & $(0.374)$ & $(0.940)$ & $(0.296)$ & $(0.175)$ \\
\hline Adjusted $R$-squared & 0.32 & 0.34 & 0.45 & 0.39 & 0.32 & 0.34 & 0.42 & 0.48 & 0.43 & 0.10 & 0.62 \\
\hline Number of countries & 23 & 23 & 23 & 23 & 23 & 23 & 23 & 23 & 22 & 18 & 23 \\
\hline Observations & 160 & 160 & 160 & 160 & 158 & 157 & 157 & 157 & 130 & 86 & 46 \\
\hline
\end{tabular}

a ${ }^{*} p<0.10,{ }^{* *} p<0.05,{ }^{* * *} p<0.01$.

b All regressions exclude observations for which $\operatorname{Ln}(U N D E R V A L)<-1.5$ and $\operatorname{Ln}(U N D E R V A L)>1.5$. 
Table 5

Dynamic panel estimation of the investment growth effects of undervaluation.

\begin{tabular}{|c|c|c|c|c|c|c|c|}
\hline \multicolumn{8}{|c|}{ Dependent variable: GROWTHGFCF (investment growth) ${ }^{\mathrm{a}, b}$} \\
\hline & $\begin{array}{l}\text { All countries } \\
\text { (1) }\end{array}$ & $\begin{array}{l}\text { Classif I } \\
\text { (2) }\end{array}$ & $\begin{array}{l}\text { Classif II } \\
\text { (3) }\end{array}$ & $\begin{array}{l}\text { Classif III } \\
\text { (4) }\end{array}$ & $\begin{array}{l}\text { Classif I } \\
\text { (5) }\end{array}$ & $\begin{array}{l}\text { Classif II } \\
\text { (6) }\end{array}$ & $\begin{array}{l}\text { Classif III } \\
\text { (7) }\end{array}$ \\
\hline (a) Lagged investment growth & $\begin{array}{l}0.213^{* * *} \\
(4.34)\end{array}$ & $\begin{array}{l}0.003 \\
(0.04)\end{array}$ & $\begin{array}{l}-0.005 \\
(-0.07)\end{array}$ & $\begin{array}{l}0.159^{* * *} \\
(3.00)\end{array}$ & $\begin{array}{l}0.216^{* * *} \\
(4.09)\end{array}$ & $\begin{array}{l}0.234^{* * *} \\
(4.52)\end{array}$ & $\begin{array}{l}0.172^{* * *} \\
(2.79)\end{array}$ \\
\hline (b) Ln intial income & $\begin{array}{l}-0.080^{* * *} \\
(-6.25)\end{array}$ & $\begin{array}{l}-01 \mathrm{SI}^{* * *} \\
(-3.66)\end{array}$ & $\begin{array}{l}-0.111^{* * *} \\
(-3.12)\end{array}$ & $\begin{array}{l}-0.109^{* * *} \\
(-6.19)\end{array}$ & $\begin{array}{l}-0.089^{* * *} \\
(-6.41)\end{array}$ & $\begin{array}{l}-0.083^{* * *} \\
(-6.09)\end{array}$ & $\begin{array}{l}-0.107^{* * *} \\
(-4.47)\end{array}$ \\
\hline (c) Ln UNDERVAL & $\begin{array}{l}0.010 \\
(0.83)\end{array}$ & $\begin{array}{l}-0.005 \\
(-0.15)\end{array}$ & $\begin{array}{l}-0.102^{* *} \\
(-2.14)\end{array}$ & $\begin{array}{l}-0.060^{* * *} \\
(-3.61)\end{array}$ & $\begin{array}{l}0.021^{*} \\
(1.66)\end{array}$ & $\begin{array}{l}0.019 \\
(1.53)\end{array}$ & $\begin{array}{l}0.038^{* * *} \\
(3.38)\end{array}$ \\
\hline (d) $\operatorname{Ln} U N D E R V A L_{M}$ & $\begin{array}{l}0.031^{* * *} \\
(2.69)\end{array}$ & $\begin{array}{l}0.048 \\
(1.64)\end{array}$ & $\begin{array}{l}0.097^{* *} \\
(2.52)\end{array}$ & $\begin{array}{l}0.026^{* *} \\
(2.30)\end{array}$ & $\begin{array}{l}0.042^{* * *} \\
(2.71)\end{array}$ & $\begin{array}{l}0.033^{* *} \\
(2.32)\end{array}$ & $\begin{array}{l}0.061^{* * *} \\
(3.44)\end{array}$ \\
\hline$(e)=[(c)+(d)] /[1-(a)]$ & 0.052 & 0.044 & -0.004 & -0.040 & 0.079 & 0.067 & 0.120 \\
\hline Wald statistic & 13.92 & 2.43 & 0.02 & 3.28 & 17.42 & 12.83 & 31.01 \\
\hline$p$-Value & $(0.000)$ & $(0.119)$ & $(0.890)$ & $(0.070)$ & $(0.000)$ & $(0.000)$ & $(0.000)$ \\
\hline Time dummies & Yes & Yes & Yes & Yes & Yes & Yes & Yes \\
\hline No. of countries & 115 & 23 & 23 & 58 & 92 & 96 & 69 \\
\hline Observations & 452 & 115 & 103 & 216 & 337 & 349 & 236 \\
\hline Instrument rank & 30 & 23 & 23 & 30 & 30 & 30 & 30 \\
\hline$J$-statistic & 23.79 & 15.50 & 16.55 & 23.06 & 23.05 & 21.10 & 22.86 \\
\hline Sargan test ( $p$-value) & 0.252 & 0.277 & 0.221 & 0.286 & 0.286 & 0.391 & 0.296 \\
\hline
\end{tabular}

a (t-statistic), ${ }^{*} p<0.10,{ }^{* *} p<0.05,{ }^{* * *} p<0.01$.

b Results obtained using the orthogonal deviations transformation and assuming exogeneity of time dummies. All regressions exclude observations for which $\operatorname{Ln}(U N D E R V A L)<-1.5$ and $\operatorname{Ln}(U N D E R V A L)>1.5$.

out dynamic panel estimations using the Arellano-Bond two-step General Method of Moments (GMM) method. We treat $\ln U N D E R V A L$ as endogenous and use its lagged values as instruments. ${ }^{23}$ Table 5 reports the main results. The long-run coefficient on In UNDERVAL (row (e)) is significant at $1 \%$ for developing countries regardless of classification type. It is reassuring to see that the values of the estimates with GMM are relatively similar to those of the baseline fixed effects OLS estimation. ${ }^{24}$ As in the OLS estimations, the individual coefficient on the first lag is large and significant, and the coefficient on the current value is positive but generally insignificant. The estimated values for the individual coefficients are also similar. ${ }^{25}$ For developed countries, the long-run coefficient is not significant under either classification I or II. For the whole sample, the estimated long-run coefficient on $\ln U N D E R V A L$ is significant at $1 \%$, but lower than that for developing countries. Overall, the results of the GMM estimations support the earlier findings.

It is possible that our results are dominated by the effects of extreme real exchange rate misalignments. Table 6, therefore, reports robustness checks for sensitivity to the magnitude of misalignment. Columns 1-3 present the results of the baseline regression applied to successively narrower ranges of $\ln U N D E R V A L$

\footnotetext{
23 Given that in the regressions reported in Table 3, the second lag of In UNDERVAL was systematically insignificant and very close to zero, we omit it from the GMM analysis. Also, since from a general equilibrium perspective $\ln R G D P H_{t-1}$ and $\ln U N D E R V A L_{t-1}$ are endogenous variables, we treated both as endogenous regressors in the GMM regressions.

24 The GMM and OLS estimates (Table 3 ) for the baseline specification are $\widehat{\delta_{0}}+\widehat{\delta_{1}}=0.079$ and 0.066 , respectively.

25 We get $\widehat{\delta_{0}}=0.012$ and $\widehat{\delta_{1}}=0.048$ in the OLS estimation, and $\widehat{\delta_{0}}=$ 0.021 and $\widehat{\delta_{1}}=0.042$ in the GMM estimation.
}

for developing countries. The long-run coefficient is always positive and significant. The estimated effect ranges from 0.046 to 0.063 . As in the previous analyses, the effect of undervaluation on investment growth operates mainly through the first lag. Columns 4-6 introduce the controls previously used in column 4 of Table 3 . Adding controls makes little difference to the magnitude or significance of results. The effect of misalignment on investment growth is significant regardless of its size.

The relevant literature has, until recently, mostly focused on the negative impact of overvaluations on growth. This suggests another possibility; namely that our results are mainly picking up the negative impact of overvaluations on accumulation, rather than a positive effect of undervaluation. Table 7 explores asymmetries in the relationship between the undervaluation index and capital accumulation. Columns (1) and (4) report the estimated coefficients for the baseline equation applied separately to developing countries with undervalued ( $\ln U N D E R V A L>0)$ and overvalued (InUNDERVAL $<0$ ) exchange rates, respectively. The long-run effect of undervaluation is marginally insignificant for countries with undervalued exchange rates and only significant at $10 \%$ for countries with overvalued exchange rates. A problem with these point criteria (i.e., $\lessgtr 0$ ) is that we do not exploit the variability produced by countries that move from one state to another (e.g. from being undervalued to being overvalued). Another limitation arises from the fact that it is impossible to have an accurate point estimate of the equilibrium real exchange rate. One way to ameliorate these limitations is by defining the equilibrium rate as a narrow band rather than a point. Columns (2) and (5) analyze the cases where equilibrium is defined as $-0.05<\ln U N D E R V A L<0.05$. Columns (3) and (6) replicate the analysis using $\mp 0.1$ as the limits. The long-run coefficient is significant for both overvaluation 
Table 6

Panel evidence on investment growth, testing for sensitivity to magnitudes.

\begin{tabular}{|c|c|c|c|c|c|c|}
\hline Dependent variable: GROWTHGFCF & $\begin{array}{l}\text { ment growth })^{\mathrm{a}, \mathrm{b}} \\
(1) \\
-1.0<\text { LnUND }<1.0\end{array}$ & $\begin{array}{l}(2) \\
-0.75<\text { LnUND }<0.75\end{array}$ & $\begin{array}{l}(3) \\
-0.5<\text { LnUND }<0.5\end{array}$ & $\begin{array}{l}(4) \\
-1.0<\text { LnUND }<1.0\end{array}$ & $\begin{array}{l}(5) \\
-0.75<\text { LnUND }<0.75\end{array}$ & $\begin{array}{l}\text { (6) } \\
-0.5<\text { LnUND }<0.5\end{array}$ \\
\hline Ln $R G D P C H_{t-1}$ & $\begin{array}{l}-0.082^{* * *} \\
(-5.70)\end{array}$ & $\begin{array}{l}-0.083^{* * *} \\
(-5.60)\end{array}$ & $\begin{array}{l}-0.098^{* * *} \\
(-6.37)\end{array}$ & $\begin{array}{l}-0.122^{* * *} \\
(-5.97)\end{array}$ & $\begin{array}{l}-0.118^{* * *} \\
(-5.65)\end{array}$ & $\begin{array}{l}-0.134^{* * *} \\
(-5.92)\end{array}$ \\
\hline Ln $U N D E R V A L_{t}$ & $\begin{array}{l}0.008 \\
(0.54)\end{array}$ & $\begin{array}{l}-0.014 \\
(-0.84)\end{array}$ & $\begin{array}{l}-0.026 \\
(-1.26)\end{array}$ & $\begin{array}{l}0.024 \\
(1.44)\end{array}$ & $\begin{array}{l}0.002 \\
(0.98)\end{array}$ & $\begin{array}{l}-0.006 \\
(-0.25)\end{array}$ \\
\hline Ln UNDERVAL $L_{t-1}$ & $\begin{array}{l}0.045^{* * *} \\
(2.92)\end{array}$ & $\begin{array}{l}0.051^{* * * *} \\
(3.21)\end{array}$ & $\begin{array}{l}0.078^{* * *} \\
(4.40)\end{array}$ & $\begin{array}{l}0.030^{*} \\
(1.79)\end{array}$ & $\begin{array}{l}0.038^{* *} \\
(2.19)\end{array}$ & $\begin{array}{l}0.064^{* * * *} \\
(3.34)\end{array}$ \\
\hline Ln UNDERVAL $L_{t-2}$ & $\begin{array}{l}0.008 \\
(0.61)\end{array}$ & $\begin{array}{l}0.010 \\
(0.69)\end{array}$ & $\begin{array}{l}0.011 \\
(0.75)\end{array}$ & $\begin{array}{l}0.000 \\
(0.00)\end{array}$ & $\begin{array}{l}0.001 \\
(0.06)\end{array}$ & $\begin{array}{l}0.006 \\
(0.37)\end{array}$ \\
\hline $\begin{array}{l}\text { Government Consumption } \\
\text { (share of GDP) }\end{array}$ & & & & $\begin{array}{l}0.144 \\
(1.13)\end{array}$ & $\begin{array}{l}0.103 \\
(0.77)\end{array}$ & $\begin{array}{l}0.102 \\
(0.74)\end{array}$ \\
\hline $\operatorname{Ln}\left(\mathrm{CPI}_{t} / \mathrm{CPI}_{t-1}\right)$ & & & & $\begin{array}{l}-0.007^{* *} \\
(-2.55)\end{array}$ & $\begin{array}{l}-0.008^{* * *} \\
(-2.68)\end{array}$ & $\begin{array}{l}-0.007^{* *} \\
(-2.31)\end{array}$ \\
\hline Ln(RER volatility) & & & & $\begin{array}{l}-0.012^{* *} \\
(-2.40)\end{array}$ & $\begin{array}{l}-0.008^{*} \\
(-1.65)\end{array}$ & $\begin{array}{l}-0.009 \\
(-1.61)\end{array}$ \\
\hline Openness & & & & $0.056^{* *}$ & $0.058^{* *}$ & 0.040 \\
\hline (Exports + Imports as share of GDP) & & & & $(2.19)$ & $(2.24)$ & $(1.40)$ \\
\hline External Debt (share of GNI) & & & & $\begin{array}{l}-0.050^{* * *} \\
(-3.78)\end{array}$ & $\begin{array}{l}-0.052^{* * *} \\
(-3.85)\end{array}$ & $\begin{array}{l}-0.042^{* * *} \\
(-2.73)\end{array}$ \\
\hline Gross Domestic Saving (Residuals) & & & & $\begin{array}{l}0.137^{* *} \\
(2.14)\end{array}$ & $\begin{array}{l}0.126^{*} \\
(1.91)\end{array}$ & $\begin{array}{l}0.155^{* *} \\
(2.22)\end{array}$ \\
\hline Time Dummies & Yes & Yes & Yes & Yes & Yes & Yes \\
\hline Country Dummies & Yes & Yes & Yes & Yes & Yes & Yes \\
\hline$L n U N D_{t}+\operatorname{LnUND_{t-1}}+\operatorname{LnUND_{t-2}}$ & 0.061 & 0.046 & 0.063 & 0.054 & 0.041 & 0.064 \\
\hline Wald statistic & 12.82 & 6.25 & 8.33 & 6.85 & 3.37 & 5.20 \\
\hline $\begin{array}{l}p \text {-Value } \\
\text { Adjusted } R \text {-squared }\end{array}$ & $\begin{array}{l}(0.000) \\
0.22\end{array}$ & $\begin{array}{l}(0.012) \\
0.22\end{array}$ & $\begin{array}{l}(0.004) \\
0.23\end{array}$ & $\begin{array}{l}(0.009) \\
0.32\end{array}$ & $\begin{array}{l}(0.067) \\
0.31\end{array}$ & $\begin{array}{l}(0.023) \\
0.29\end{array}$ \\
\hline Number of countries & 126 & 123 & 113 & 98 & 95 & 86 \\
\hline Observations & 540 & 518 & 463 & 411 & 394 & 347 \\
\hline
\end{tabular}

a ${ }^{*} p<0.10,{ }^{* *} p<0.05,{ }^{* * *} p<0.01$.

b All regressions exclude observations for which $\operatorname{Ln}(U N D E R V A L)<-1.5$ and $\operatorname{Ln}(U N D E R V A L)>1.5$. 
Table 7

Panel evidence on investment growth, testing for asymmetries.

\begin{tabular}{|c|c|c|c|c|c|c|}
\hline \multicolumn{7}{|c|}{ Dependent variable: GROWTHGFCF (investment growth) } \\
\hline & \multicolumn{3}{|c|}{ Undervalued RER } & \multicolumn{3}{|c|}{ Overvalued RER } \\
\hline & $(1)$ & $(2)$ & (3) & (4) & $(5)$ & $(6)$ \\
\hline & $\operatorname{Ln} U N D>0$ & $\operatorname{Ln} U N D>-0.05$ & $\operatorname{Ln} U N D>-0.10$ & $\operatorname{Ln} U N D<0$ & $\operatorname{Ln} U N D<0.05$ & $\operatorname{Ln} U N D<0.10$ \\
\hline $\operatorname{Ln} R G D P C H_{t-1}$ & $-0.083^{* * *}$ & $-0.081^{* * *}$ & $-0.094^{* * *}$ & $-0.119^{* * *}$ & $-0.108^{* * *}$ & $-0.070^{* * *}$ \\
\hline & $(-4.12)$ & $(-4.31)$ & $(-5.12)$ & $(-3.53)$ & $(-3.46)$ & $(-2.74)$ \\
\hline $\operatorname{LnUNDERVAL_{t}}$ & $-0.049^{*}$ & $-0.043^{*}$ & -0.023 & 0.053 & $0.053^{*}$ & 0.045 \\
\hline & $(-1.90)$ & $(-1.77)$ & $(-1.07)$ & $(1.64)$ & $(1.69)$ & $(1.59)$ \\
\hline $\operatorname{Ln} U N D E R V A L_{t-1}$ & $0.066^{* * *}$ & $0.068^{* * *}$ & $0.065^{* * *}$ & 0.030 & 0.022 & 0.033 \\
\hline & $(3.38)$ & $(3.84)$ & $(3.62)$ & $(1.10)$ & $(0.82)$ & $(1.30)$ \\
\hline $\operatorname{LnUNDERVAL_{t-2}}$ & 0.026 & 0.019 & 0.006 & -0.012 & -0.007 & -0.002 \\
\hline & $(1.31)$ & $(1.07)$ & $(0.38)$ & $(-0.50)$ & $(-0.32)$ & $(-0.11)$ \\
\hline Time Dummies & Yes & Yes & Yes & Yes & Yes & Yes \\
\hline Country Dummies & Yes & Yes & Yes & Yes & Yes & Yes \\
\hline $\operatorname{Ln} U N D_{t}+\operatorname{Ln} U N D_{t-1}+\operatorname{Ln} U N D_{t-2}$ & 0.043 & 0.045 & 0.048 & 0.072 & 0.067 & 0.075 \\
\hline Wald statistic & 2.19 & 3.14 & 4.09 & 2.81 & 2.72 & 4.13 \\
\hline$p$-Value & $(0.139)$ & $(0.077)$ & $(0.044)$ & $(0.095)$ & $(0.100)$ & $(0.043)$ \\
\hline Adjusted $R$-squared & 0.40 & 0.39 & 0.34 & 0.04 & 0.02 & 0.08 \\
\hline Number of countries & 104 & 108 & 110 & 85 & 92 & 101 \\
\hline Observations & 327 & 367 & 399 & 225 & 260 & 297 \\
\hline
\end{tabular}

a ${ }^{*} p<0.10,{ }^{* *} p<0.05,{ }^{* * *} p<0.01$.

b All regressions exclude observations for which $\operatorname{Ln}(U N D E R V A L)<-1.5$ and $\operatorname{Ln}(U N D E R V A L)>1.5$.

and undervaluation, indicating that while the former promotes investment growth in developing countries, the latter undermines it. ${ }^{26}$

The evidence reported in this section suggests that real undervaluations have a positive effect on investment growth mainly for developing countries. This conclusion results from two sources. First, we found that $\ln U N D E R V A L$ interacts negatively with the level of real GDP per capita, indicating that its effect on investment growth decreases with countries' income level. Second, using our various classifications of developed and developing countries, we found that the effect of undervaluation on investment growth is large and significant only for the latter. The small sample size for developed countries somewhat limits the confidence with which we can assess the results, but additional support comes from the coefficient on the interaction term in Table 2, and from fact that the long-run effect of $\ln U N D E R V A L$ is insignificant for the whole sample (Table 2 ), but significant for developing countries (Table 3 ). These findings are robust to econometric methodology and degrees of exchange rate misalignment.

We conclude this section by noting that our estimates yield a negative and statistically significant effect of real exchange rate volatility in almost all cases. This underlines the importance of minimizing real exchange rate uncertainty. In light of Eq. (26), it also highlights, for a policy regime targeting rapid accumulation sans external imbalances, the need to maintain a consistent policy towards investment promotion (i.e., a stable $\gamma$ ). Volatility of the RER introduces volatility in the profit rate and in terms of the model, this may produce a downward shift in the

\footnotetext{
26 Tightening the band to $\mp 0.01$ yields similarly significant results. Also, we conducted the same analysis using the period $t-1$ to determine whether the exchange was undervalued or overvalued and obtained qualitatively similar results. These are reported in the available-on-request appendix.
}

investment function (15). Considering that manipulating $\gamma$ is likely to be institutionally intensive, it is perhaps not surprising that tight control of credit was a distinguishing feature of several successful countries such as South Korea in their initial stages of development. Such consistency may arguably have been lacking historically in many other developing countries where institutional and socioeconomic barriers have hindered policy stability.

\section{Conclusions}

The theoretical part of this paper analyzed an economy with significant amounts of open and/or hidden unemployment. In this economy, non-tradable output and employment are demand-led, and an investment stimulus can affect both the level of output and the growth rate. But growth is not export-led in the sense of net exports acting as a necessary driver of demand. Instead, there is a close affinity with the argument presented by Rodrik (1997) who saw investment promotion rather than exports as key to growth in Taiwan and Korea. Investment promotion, however, has implications for the balance of payments and requires a suitable real exchange rate policy in order to be sustainable. Thus, the real exchange rate becomes a critical element of successful development.

The model highlights the mobilization of underemployed resources as a source of economic growth, and to simplify the analysis we deliberately left out other potential explanations of the link between exchange rates and economic performance. An alternative approach focuses on dynamic effects associated with learning by doing or other growth enhancing externalities in the tradable sector. Rodrik (2008) gives a full-employment version of this argument. Tradable production, he suggests, is strongly afflicted by institutional weaknesses and market failures, and these problems lead to a bias against this sector in resource allocation. Exchange rate undervaluation boosts profits in 
the tradable sector and the resulting sectoral reallocation raises the growth rate in an AK-type model of endogenous growth. ${ }^{27}$ Rodrik's full employment assumption is questionable, but unemployment and scale economies clearly are not mutually exclusive. Kaldor (1966) built the theoretical argument for his 'growth laws' around a combination of dynamic increasing returns to scale in industry and the existence of hidden unemployment, and a large literature has developed and extended his analysis. The real exchange rate, however, has played a limited role in this literature, and an examination of the interaction between the mobilization and scale effects of the real exchange rate is left for future research, as is the issue of embodied technical change.

The empirical part explores the main implication of our model: the existence of a positive relationship between real exchange rate undervaluation and investment growth. If, as suggested by the model, the presence of underemployment and reliance on imported capital goods constitute important channels through which the real exchange rate affects the economy, targeting the latter may be more effective in promoting accumulation and employment in low income developing countries compared to developed countries. Our econometric results, which are robust to a variety of classifications, controls, sample periods, and estimation techniques provide support to this prediction.

\section{Acknowledgements}

We are also grateful to the referees for their helpful comments.

\section{Appendix A. Extension: respecifying workers' consumption}

As a more general specification, one could allow for saving out of wage income, with saving propensities that depend on both sector and income category, and let the composition of consumption depend on the source of income. Thus, let $s_{w}$ and $s_{r}$ represent the saving rates out of wages and rents in the non-tradable sector and $\sigma_{w}$ and $\sigma_{p}$ the corresponding rates for the tradable sector, and let $\alpha_{p}$ and $\alpha_{w}$ be the shares of non-tradables in the consumption out of profits/rents and wages. The equilibrium condition for the non-tradable can now be written

$$
\begin{aligned}
Y_{N}= & \alpha_{w}\left(1-s_{w}\right) v \beta Y_{N}+\alpha_{w}\left(1-\sigma_{w}\right) W_{T} \\
& +\alpha_{p}\left(1-s_{r}\right)(1-v \beta) Y_{N}+\alpha_{p}\left(1-\sigma_{p}\right)\left(q Y_{T}-W_{T}\right)
\end{aligned}
$$

where

$$
W_{T}=\phi\left(\frac{b K}{a}, q, s_{w}, s_{r}, \sigma_{w}, \sigma_{p}\right) \frac{b K}{a}
$$

\footnotetext{
27 It should be noted that even if the magnitude of the externalities is insufficient to allow for permanent endogenous growth in a closed economy, they may generate multiple equilibria in an open economy, and a temporary exchange rate shock can send the economy to a new long run equilibrium (Krugman, 1987; Ros and Skott, 1998; Rapetti, 2011).
}

is the wage bill in the tradable sector. Solving for $Y_{N}$ and substituting into the expression for $E_{T}$, we get

$E_{T}=A Y_{T}+\frac{B}{q} W_{T}$

where

$$
\begin{aligned}
A= & \left(1-\sigma_{p}\right)-\alpha_{p}\left(1-\sigma_{p}\right) \frac{s_{w} \nu \beta+s_{r}(1-\nu \beta)}{1-\alpha_{w}\left(1-s_{w}\right) \nu \beta-\alpha_{p}\left(1-s_{r}\right)(1-\nu \beta)} \\
B= & \left(\sigma_{p}-\sigma_{w}\right)-\left[\left(1-\sigma_{w}\right) \alpha_{w}-\left(1-\sigma_{p}\right) \alpha_{p}\right] \\
& \frac{s_{w} \nu \beta+s_{r}(1-\nu \beta)}{1-\alpha_{w}\left(1-s_{w}\right) \nu \beta-\alpha_{p}\left(1-s_{r}\right)(1-\nu \beta)}
\end{aligned}
$$

The value of $A$ is decreasing in $q$ as long as the substitutability condition is satisfied for both $\alpha_{p}$ and $\alpha_{w}\left(\alpha_{p}^{\prime}(q)>\right.$ $\left.0, \alpha_{w}(q)>0\right)$. Hence, the condition $\partial\left((B / q) W_{T}\right) / \partial q \leq 0$ is sufficient to ensure that the domestic demand for tradables will be inversely related to the real exchange rate. Our specification in Section 2 emerges as a special case with $\alpha_{w}=1, s_{w}=\sigma_{w}=0, s_{r}=\sigma_{p}=s>0$. Another simple case arises with uniform saving rates and consumption compositions $\left(\alpha_{w}=\alpha_{p}\right.$ and $\left.s_{w}=\sigma_{w}=s_{r}=\sigma_{p}=s>0\right)$. Both of these cases satisfy the above stated condition since, in both cases, $B \equiv 0$.

\section{Appendix B. Distributional effects}

Changes in real exchange rates influence income distribution. The wage share of total output can be written

$$
\frac{\omega_{N} L_{N}+\omega_{T} L_{T}}{Y_{N}+q Y_{T}}=\frac{\omega_{N} L_{N}}{Y_{N}} \frac{Y_{N}}{Y_{N}+q Y_{T}}+\frac{\omega_{T} L_{T}}{q Y_{T}}\left(1-\frac{Y_{N}}{Y_{N}+q Y_{T}}\right)
$$

Hence, the change in the wage share becomes

$$
\begin{aligned}
d\left(\frac{\omega_{N} L_{N}+\omega_{T} L_{T}}{Y_{N}+q Y_{T}}\right)= & \frac{Y_{N}}{Y_{N}+q Y_{T}} d\left(\frac{\omega_{N} L_{N}}{Y_{N}}\right) \\
& +\left(1-\frac{Y_{N}}{Y_{N}+q Y_{T}}\right) d\left(\frac{\omega_{T} L_{T}}{q Y_{T}}\right) \\
& +\left(\frac{\omega_{N} L_{N}}{Y_{N}}-\frac{\omega_{T} L_{T}}{q Y_{T}}\right) d\left(\frac{Y_{N}}{Y_{N}+q Y_{T}}\right)
\end{aligned}
$$

By assumption the wage share in the non-tradable sector is constant $\left(\omega_{N} L_{N} / Y_{N}=v \beta\right)$ so the first term on the right hand side is zero. The signs of the second and third terms, however, are both ambiguous. The ambiguity may seem surprising from the perspective of Kaleckian open economy models which typically view the wage share as inversely related to the real exchange rate (e.g. Blecker (1999)). This inverse relation can arise either because a constant markup is applied to costs that include imported raw materials and intermediate goods, or because a real depreciation reduces the competitive pressures from abroad and lead to a rise in the markup. The ambiguity in our model has two sources. The economy-wide wage share is a weighted average of the wage shares in the traded and non-traded sectors, and real depreciation affects the weights. Secondly, although the direct impact of a real depreciation on the wage share in the traded sector is negative, this direct effect can be dominated by indirect effects. A real depreciation is expansionary: the traded sector employment is determined by the capital stock, and the change in the terms of trade boosts the demand for non-traded goods. Increasing employment strengthens workers and raises nominal 
wages. Traded good prices are determined in the world market - an extreme version of the competitive pressures in the Kaleckian model - and although empirically unlikely, in principle the net result can be a rise in the traded-sector wage share.

Turning to the wage rate, our (strong) assumption about the composition of workers' consumption implies that a growth policy and the associated real depreciation raise the consumption real wage in the formal sector as well as the effective employment and the average remuneration in the traditional sector. These results, which hold for a given capital stock, are reinforced by the positive effects of higher accumulation on wages and employment in both sectors. Fast growth, by construction, is generated by raising the rate of return relative to the cost of finance in the tradable sector, and it follows that workers and tradable-sector capitalists have a shared interest in growth. Distributional conflicts between workers and capitalists may emerge if workers consume tradables and the wage function $\phi$ is insensitive to changes in $q$, but as long as the share of tradables in workers' consumption remains small, the consumption real wage would decline much less, proportionately, than the product real wage.

Opposition to a growth policy that involves a real depreciation could come from landlords. By lowering the real wage in the traditional sector, a depreciation increases rents, but the change in the relative price may reduce the real value of rents. Depending on the composition of landlord consumption (and thus the relevant price index), the net effect could go either way.

\section{Appendix C. Deriving the index of real exchange rate misalignment}

We follow the three-step methodology pursued by Rodrik (2008) to obtain an index of real exchange rate undervaluation. Using data from Penn World Tables 6.2 (Heston et al., 2006), we first calculate the real exchange rate $(R E R)$ as the ratio between the nominal exchange rate $(X R A T)$ and the purchasing power parity conversion factor $(P P P)$. We use a 5-year frequency, in which each observation corresponds to the period average. Both variables are expressed as national currency units per U.S. dollar. However, since PPP is calculated over the entire GDP, the basket includes non-tradables for which we do not expect the law of one price to hold. Thus, in order to calculate equilibrium real exchange rates, in a second step we adjust for the Balassa-Samuelson (BS) effect, regressing RER on real GDP per capita $(R G D P C H)$ :

$\ln R E R_{i t}=\alpha+\beta \ln R G D P C H_{i t}+f_{t}+\varepsilon_{i t}$

where $i$ and $t$ are country and time indexes, respectively, $f_{t}$ accounts for time fixed effects, and $\varepsilon_{i t}$ is the error term. We obtain an estimate of $\widehat{\beta}=-0.24$, with a t-statistic of 21.29. The sign of the coefficient is in line with the Balassa-Samuelson prediction; in this case, a $10 \%$ increase in $R G D P C H$ is associated with a $2.4 \%$ real appreciation. Finally, we define the undervaluation index (UNDER$V A L)$ as the ratio of actual to BS-adjusted real exchange rates: $U N D E R V A L_{i t}=R E R_{i t} / \widehat{R E R_{i t}}$. Defined in index form,
UNDERVAL is comparable across countries and over time; when it exceeds unity, the domestic currency is undervalued in real terms (i.e., domestic goods are cheap in international dollar terms). We use $\ln U N D E R V A L$ as the main variable of interest; it has a zero mean and a standard deviation of 0.47 .

\section{References}

Bahmani-Oskoee, M., Hajilee, M., 2010. On the relation between currency depreciation and domestic investment. Journal of Post Keynesian Economics 32 (4), 645-660.

Bahmani-Oskoee, M., Niroomand, F., 1998. Long-run price elasticities and the Marshall-Lerner condition revisited. Economics Letters 61, $101-109$.

Barro, R.J., Lee, J.-W., 2000. International data on educational attainment: Updates and implications. Working Paper 42, April, Center for International Development, Harvard University, Harvard.

Berg, A., Ostry, J.D., Zettelmeyer, J., 2008. What makes growth sustained? Working Paper 08/59, March, International Monetary Fund, Washington, DC.

Blecker, R., 1999. Kaleckian macro models for open economies. In: Johan, D., Harvey, T., John (Eds.), Foundations of International Economics: Post Keynesian Perspectives. Routledge, London.

Blecker, R., Razmi, A., 2008. The contractionary short-run effects of nominal devaluation in developing countries: some neglected nuances. Cambridge Journal of Economics 32 (1), 83-109.

Blecker, R.A., 2002. Distribution, demand and growth in neo-Kaleckian macro models. In: Setterfield, M. (Ed.), The Economics of Demand-Led Growth: Challenging the Supply-Side Vision of the Long-Run. Edward Elgar.

Calvo, G., Reinhart, C., 2002. The fear of floating. Quarterly Journal of Economics CXVII (May (2)), 379-408

Campa, J.M., Goldberg, L.S., 1999. Investment, pass-through, and exchange rates: a cross-country comparison. International Economic Review 40 (August (2)), 287-314

Chinn, M. Wei, S.-J., 2008. A faith-based initiative: Does a flexible exchange rate regime really facilitate current account adjustment? Technical Report 14420, National Bureau of Economic Research.

Fisher, I., 1933. The debt-deflation theory of great depressions. Econometrica 1 (4), 337-357.

Flaschel, P., Skott, P., 2006. Steindlian models of growth and stagnation. Metroeconomica 57 (3), 303-338.

Gala, P., 2008. Real exchange rate levels and economic development: theoretical analysis and econometric evidence. Cambridge Journal of Economics 32 (2), 273-288.

Hausmann, R., Pritchett, L., Rodrik, D., 2005. Growth accelerations. Journal of Economic Growth 10, 303-329.

Heston, A., Summers, R., Aten, B., 2006. Penn World Table version 6.2. Technical report, May, Center for International Comparisons of Production, Income and Prices at the University of Pennsylvania.

Kaldor, N., 1966. Causes of the Slow Rate of Economic Growth of the United Kingdom: An Inaugural Lecture. Cambridge University Press, Cambridge.

Kaufmann, D., Kraay, A., Mastruzzi, M., 2008. Governance matters vii: aggregate and individual governance indicators, 1996-2007. Technical Report 4654, World Bank Policy Research Working Paper, Washington, DC

Keynes, J.M., 1936. The General Theory of Employment, Interest and Money. Macmillan Cambridge University Press, Cambridge.

Krugman, P., 1987. The narrow moving band, the Dutch disease, and the competitive consequences of Mrs. Thatcher: notes on trade in the presence of dynamic scale economies. Journal of Development Economics 27, 41-55.

Kuijs, L., 2006. How will China's saving-investment balance evolve? Working Paper 3958, July, World Bank, Washington, DC.

LABORSTA, 2009. LABORSTA Internet. On-line Database. International Labour Organisation, Geneva.

Levy-Yeyati, E., Sturzenegger, F., 2007. Fear of appreciation. Policy Research Working Paper 4387, November, The World Bank, Washington, DC.

Meese, R., Rogoff, K., 1983. Empirical exchange rate models of the seventies. Do they fit out of sample? Journal of International Economics 14, $3-24$.

Polterovich, V., Popov, V., 2002. Accumulation of foreign exchange reserves and long term growth. Technical report, New Economic School. 
Porcile, G., Lima, G.T., 2010. Real exchange rate and elasticity of labour supply in a balance-of-payments-constrained macrodynamics. Cambridge Journal of Economics 34(6), 1019-1039.

Prasad, E., Rajan, R., Subramanian, A., 2007. Foreign capital and economic growth. Brookings Papers on Economic Activity 1, 1-57.

Rapetti, M., 2011. Macroeconomic policy coordination in a competitive real exchange rate strategy for development. Working Paper 2011-09, June, University of Massachusetts, Amherst, MA.

Rapetti, M., Skott, P., Razmi, A., 2011. The real exchange rate and economic growth: are developing countries different? Working Paper 2011-07, May, University of Massachusetts, Amherst, MA.

Razin, O., Collins, S., 1997. Real exchange rate misalignments and growth. Working Paper 6174, September, National Bureau for Economic Research, Cambridge, MA.

Rodrik, D., 1997. Trade strategy, investment and export: another look at East Asia. Pacific Economic Review 2 (February (1)), 1-24.
Rodrik, D., 2008. The real exchange rate and economic growth. Brookings Papers on Economic Activity 2, 365-412.

Rodrik, D., 2009. Growth after the crisis. Working Paper 65, Commission on Growth and Development, Washington, DC.

Ros, J., Skott, P., 1998. Dynamic effects of trade liberalization and currency overvaluation under conditions of increasing returns. The Manchester School of Economic and Social Studies 66 (4), 466-489.

Thirlwall, A.P., 1979. The balance of payments constraint as an explanation of international growth rate differences. Banca Nazionale del Lavoro Quarterly Review XXXII (128), 45-53.

Wang, L., Szirmai, A., 2008. Regional capital inputs in Chinese industry and manufacturing, 1978-2003. Research Memorandum GD-99, April. Groningen Growth and Development Centre, Groningen.

World Bank, 2007. China: Quarterly Update. Technical report, February, The World Bank, Washington, DC. 